\title{
Effect of the Preparation Method of LaSrCoFeOx Perovskites on the Activity of $\mathrm{N}_{2} \mathrm{O}$ Decomposition
}

\author{
Nia Richards ${ }^{1} \cdot$ Luke A. Parker $^{1,2}$. James H. Carter ${ }^{1}$. Samuel Pattisson ${ }^{1}$ - David J. Morgan ${ }^{1} \cdot$ Nicholas F. Dummer $^{1}$. \\ Stanislaw E. Golunski ${ }^{1}$. Graham J. Hutchings ${ }^{1}$
}

Received: 22 February 2021 / Accepted: 1 April 2021 / Published online: 8 April 2021

(c) The Author(s) 2021

\begin{abstract}
$\mathrm{N}_{2} \mathrm{O}$ remains a major greenhouse gas and contributor to global warming, therefore developing a catalyst that can decompose $\mathrm{N}_{2} \mathrm{O}$ at low temperatures is of global importance. We have investigated the use of $\mathrm{LaSrCoFeO}_{x}$ perovskites for $\mathrm{N}_{2} \mathrm{O}$ decomposition and the effect of surface area, A and B site elements, $\mathrm{Co}-\mathrm{O}$ bond strength, redox capabilities and oxygen mobility have been studied. It was found that by using a citric acid preparation method, perovskites with strong redox capabilities and weak $\mathrm{Co}-\mathrm{O}$ bonds can be formed at relatively low calcination temperatures $\left(550^{\circ} \mathrm{C}\right)$ resulting in highly active catalysts. The enhanced activity is related to the presence of highly mobile oxygen species. Oxygen recombination on the catalyst surface is understood to be a prominent rate limiting step for $\mathrm{N}_{2} \mathrm{O}$ decomposition. Here the reduced strength of $\mathrm{Co}-\mathrm{O}$ bonds and mobile lattice oxygen species suggest that the surface oxygen species have enhanced mobility, aiding recombination, and subsequent regeneration of the active sites. $\mathrm{La}_{0.75} \mathrm{Sr}_{0.25} \mathrm{Co}_{0.81} \mathrm{Fe}_{0.19} \mathrm{O}_{\mathrm{x}}$ prepared by citric acid method converted $50 \%$ of the $\mathrm{N}_{2} \mathrm{O}$ in the feed $\left(\mathrm{T}_{50}\right)$ at $448{ }^{\circ} \mathrm{C}$.
\end{abstract}

\section{Graphic Abstract}

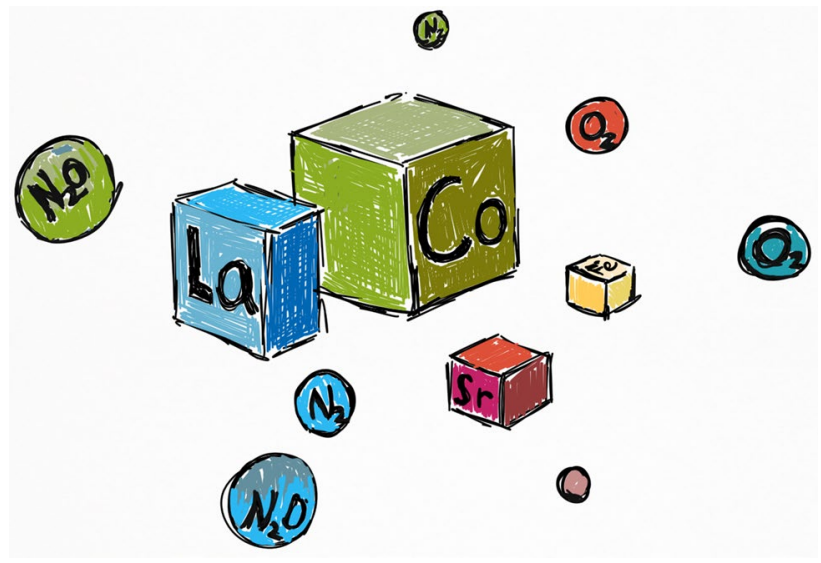

Keywords Perovskite $\cdot$ Nitrous oxide decomposition $\cdot$ Oxygen vacancies $\cdot$ Mobile lattice oxygen $\cdot$ Surface area $\cdot$ Co-O bond strength

Nia Richards

RichardsN8@ cardiff.ac.uk

Graham J. Hutchings

Hutch@ cardiff.ac.uk

Extended author information available on the last page of the article

\section{Introduction}

Nitrous oxide $\left(\mathrm{N}_{2} \mathrm{O}\right)$ has long been considered a potent greenhouse gas and, although only accounting for $332 \mathrm{ppb}$ of the atmosphere, the consequences of uncontrolled emission could be significant with respect to climate change [1]. 
$\mathrm{N}_{2} \mathrm{O}$ has a global warming potential of $c a .300$ times that of $\mathrm{CO}_{2},[2,3]$ a half-life of double that of $\mathrm{CO}_{2}(114$ years compared to an average of 31 years), [4] and an ozone depletion potential comparable to many hydrochlorofluorocarbons (HCFCs). The majority (60\%) of global $\mathrm{N}_{2} \mathrm{O}$ emissions are generated via anthropogenic sources such as industrial chemical processes including adipic acid production, sewage treatment, the agriculture sector or combustion sources $[5,6]$. There are also a number of smaller scale unregulated anthropogenic sources such as hospitals, dental surgeries and veterinary practices where $\mathrm{N}_{2} \mathrm{O}$ is used as an anaesthetic and analgesic [7]. Therefore, the development of catalysts that can effectively decompose $\mathrm{N}_{2} \mathrm{O}$ (Eq. 1) is of great significance [8].

$$
2 \mathrm{~N}_{2} \mathrm{O} \rightarrow 2 \mathrm{~N}_{2}+\mathrm{O}_{2} \quad\left(\Delta_{r} \mathrm{H}^{\mathrm{o}}(298 \mathrm{~K})=-163 \mathrm{~kJ} \mathrm{~mol}^{-1}\right)
$$

The importance of finding a suitable catalyst for $\mathrm{N}_{2} \mathrm{O}$ decomposition has been known for many years and subsequently there have been various classes of materials that have been used as catalysts, such as ceria-based materials $[9,10]$, spinels $[11,12]$ and supported metal nanoparticles $[13,14]$. Perovskites are represented by the general formula $\mathrm{ABO}_{3}$, where the A site is generally a large rare earth element such as La and the B site typically a smaller transition metal such as Co or Fe. The A site cation is generally catalytically inactive but alters the oxidation state of the B site therefore creating oxygen vacancies [15]. The $\mathrm{A}$ sites are typically cations with a charge of $2+/ 3+$, whereas, the $\mathrm{B}$ site cations have a charge of $3+/ 4+$. A second A site cation can be incorporated into the structure and the difference in valence state between the cations can lead to further oxygen vacancies or redox couples. Sr or Ce are often used for A site substitution [8]. A perovskite consists of two or more simple oxides that have a high melting point, and the preparation of a perovskite structure requires high temperature and a long calcination time, which typically leads to high structural and thermal stability $[16,17]$. The high temperatures required for the preparation of perovskites typically produce materials with low specific surface areas, usually less than $10 \mathrm{~m}^{2} \mathrm{~g}^{-1}$ $[16,18]$. However, significant work has been undertaken to produce high surface area perovskite materials $[19,20]$. The use of perovskites as solar cells has generated a significant interest in the preparation of these materials [21, 22] and perovskites now show comparable results to that of commercial solar cells [23]. It has been shown previously that oxygen mobility, ease of oxygen vacancy formation, and oxygen storage capacity of a perovskite system can influence the catalytic activity [24, 25]. The oxidation state of the B site cation and the resulting oxygen vacancy can be controlled by substitution of an external cation into the matrix. For example, if a $\mathrm{B}$ site cation oxidation state is reduced from $\mathrm{B}^{4+}$ to $\mathrm{B}^{3+}$ an oxygen vacancy can be formed, due to fewer oxygen atoms being required to balance the charge of the cation. Alternatively, an oxygen vacancy can also be formed by the substitution of an $\mathrm{A}^{3+}$ cation with that of an $\mathrm{A}^{2+}$ one in the $\mathrm{ABO}_{3}$ structure. Oxygen vacancies can provide adsorption sites for reactants and subsequent activation can take place, hence their presence in the perovskite structure can be directly linked to their catalytic activity [26].

The most notable perovskite catalysts for $\mathrm{N}_{2} \mathrm{O}$ decomposition are presented in Table 1. For example, Russo et al. utilised a solution combustion synthesis method to prepare a $\mathrm{LaCoO}_{3}$ and reported $100 \%$ conversion under conditions of $0.5 \% \mathrm{~N}_{2} \mathrm{O}$ in $\mathrm{He}$ at $550{ }^{\circ} \mathrm{C}$, with a $\mathrm{T}_{50}$ of $455^{\circ} \mathrm{C}$ and an $\mathrm{N}_{2} \mathrm{O}$ decomposition rate of $1.3 \mathrm{~mol} \mathrm{~h}^{-1} \mathrm{~kg}^{-1}$ at $450{ }^{\circ} \mathrm{C}$ [27]. Ivanov et al. prepared a series of $\mathrm{LaSrMnO}_{3}$ catalysts, investigating the effects of the ratio of $\mathrm{La}$ and $\mathrm{Sr}$ metals in the A site. The optimal $\mathrm{La} / \mathrm{Sr}$ ratio was found to be $\mathrm{La}_{0.5} \mathrm{Sr}_{0.5}$, resulting in a $\mathrm{T}_{50}$ of $750{ }^{\circ} \mathrm{C}$, under conditions

Table 1 Table showing the most relevant perovskites for $\mathrm{N}_{2} \mathrm{O}$ decomposition

\begin{tabular}{|c|c|c|c|c|c|}
\hline Perovskite & Conditions & Conversion and $\mathrm{T}_{50}{ }^{\mathrm{a}}$ & $\begin{array}{l}\mathrm{N}_{2} \mathrm{O} \text { decomposition rate } \\
\text { at } 450{ }^{\circ} \mathrm{C}\left(\mathrm{mol} \mathrm{h}^{-1} \mathrm{~kg}^{-1}\right)\end{array}$ & $\begin{array}{l}\text { Specific surface } \\
\text { area }\left(\mathrm{m}^{2} \mathrm{~g}^{-1}\right)\end{array}$ & Ref. \\
\hline $\mathrm{LaCoO}_{3}$ & $\begin{array}{l}0.5 \% \mathrm{~N}_{2} \mathrm{O} \\
\text { WHSV }=120,000 \mathrm{~mL} \mathrm{~g}^{-1} \mathrm{~h}^{-1}\end{array}$ & $\mathrm{~T}_{50}$ at $455^{\circ} \mathrm{C} 100 \%$ at $550{ }^{\circ} \mathrm{C}$ & 1.3 & 7.7 & {$[27]$} \\
\hline $\mathrm{La}_{0.4} \mathrm{Sr}_{0.6} \mathrm{FeO}_{3}$ & $\begin{array}{l}0.15 \% \mathrm{~N}_{2} \mathrm{O} \\
\text { Contact time } 5 \times 10^{-4} \mathrm{~s}\end{array}$ & $\mathrm{~T}_{50}$ at $815^{\circ} \mathrm{C}$ & $\begin{array}{l}0^{*} \\
\left(0.04 \text { at } 815^{\circ} \mathrm{C}\right)\end{array}$ & 1 & {$[28]$} \\
\hline $\mathrm{Pr}_{0.8} \mathrm{Ba}_{0.2} \mathrm{MnO}_{3}$ & $0.5 \% \mathrm{~N}_{2} \mathrm{O}, \mathrm{GHSV}=7,500 \mathrm{~h}^{-1}$ & $\mathrm{~T}_{50}$ at $442{ }^{\circ} \mathrm{C} 100 \%$ at $550^{\circ} \mathrm{C}$ & 1.2 & 12 & [29] \\
\hline $\mathrm{La}_{0.5} \mathrm{Sr}_{0.5} \mathrm{MnO}_{3}$ & $\begin{array}{l}0.15 \% \mathrm{~N}_{2} \mathrm{O} \\
\mathrm{GHSV}=30,800 \mathrm{~h}^{-1}\end{array}$ & $\mathrm{~T}_{50}$ at $750{ }^{\circ} \mathrm{C}$ & $\begin{array}{l}0^{*} \\
\left(0.04 \text { at } 750{ }^{\circ} \mathrm{C}\right)\end{array}$ & 4.1 & {$[30,31]$} \\
\hline $\mathrm{La}_{0.7} \mathrm{Ba}_{0.3} \mathrm{Mn}_{0.8} \mathrm{In}_{0.2} \mathrm{O}_{3}$ & $\begin{array}{l}10 \% \mathrm{~N}_{2} \mathrm{O} \\
\mathrm{GHSV}=21,220 \mathrm{~h}^{-1}\end{array}$ & $\begin{array}{l}\mathrm{T}_{50} \text { at } 443{ }^{\circ} \mathrm{C} \\
92 \% \text { at } 500{ }^{\circ} \mathrm{C}\end{array}$ & 5.9 & 8 & {$[32]$} \\
\hline $\mathrm{Pr}_{0.75} \mathrm{Ba}_{0.25} \mathrm{CoO}_{3}$ & $\begin{array}{l}1 \% \mathrm{~N}_{2} \mathrm{O} \\
\mathrm{GHSV}=38,000 \mathrm{~h}^{-1}\end{array}$ & $\mathrm{~T}_{50}$ at $410{ }^{\circ} \mathrm{C} 100 \%$ at $500{ }^{\circ} \mathrm{C}$ & 32 & 30 & {$[33]$} \\
\hline
\end{tabular}

${ }^{\text {a }}$ Temperature required to achieve $50 \% \mathrm{~N}_{2} \mathrm{O}$ conversion.

*No activity at $600{ }^{\circ} \mathrm{C}$. 
of $0.15 \% \mathrm{~N}_{2} \mathrm{O}$, and a Gas Hourly Space Velocity (GHSV) of $30,800 \mathrm{~h}^{-1}[30,31]$. The group then studied the effect of oxygen mobility on $\mathrm{La}_{0.4} \mathrm{Sr}_{0.6} \mathrm{FeO}_{3}$, by doping $\mathrm{LaSrFeO}_{4}$ ferrite into the structure. The $\mathrm{La}_{0.4} \mathrm{Sr}_{0.6} \mathrm{FeO}_{3}$ doped with ca. $10 \mathrm{wt} \% \mathrm{LaSrFeO}_{4}$ was the most active catalyst, with a $\mathrm{T}_{50}$ of $815^{\circ} \mathrm{C}$ under the same conditions. The improvement in activity was attributed to the increased mobility of lattice oxygen, highlighting how this is a key factor for $\mathrm{N}_{2} \mathrm{O}$ decomposition [28].

Takita et al. probed the effect of varying A and B site metal ratios on $\mathrm{N}_{2} \mathrm{O}$ decomposition using a $\mathrm{LaBaMnInO}_{3}$ catalyst. The most active catalyst was considered to be $\mathrm{La}_{0.7} \mathrm{Ba}_{0.3} \mathrm{Mn}_{0.8} \mathrm{In}_{0.2} \mathrm{O}_{3}$, converting $92 \% \mathrm{~N}_{2} \mathrm{O}$ at $500{ }^{\circ} \mathrm{C}\left(\mathrm{T}_{50}\right.$ $443{ }^{\circ} \mathrm{C}$ and $\mathrm{N}_{2} \mathrm{O}$ decomposition rate of $5.9 \mathrm{~mol} \mathrm{~h}^{-1} \mathrm{~kg}^{-1}$ at $450{ }^{\circ} \mathrm{C}$ ) under conditions of $10 \% \mathrm{~N}_{2} \mathrm{O}$ in $\mathrm{He}$ at $20 \mathrm{~mL} \mathrm{~min}^{-1}$ [32]. Kumar et al. reported that it is possible to achieve a similar $\mathrm{T}_{50}$ using a $\mathrm{Pr}_{0.8} \mathrm{Ba}_{0.2} \mathrm{MnO}_{3}$ catalyst prepared by impregnation. $\mathrm{Pr}_{0.8} \mathrm{Ba}_{0.2} \mathrm{MnO}_{3}$ catalyst was able to achieve $100 \% \mathrm{~N}_{2} \mathrm{O}$ conversion at $550{ }^{\circ} \mathrm{C}$ $\left(\mathrm{N}_{2} \mathrm{O}\right.$ decomposition rate of $1.2 \mathrm{~mol} \mathrm{~h}^{-1} \mathrm{~kg}^{-1}$ at $450{ }^{\circ} \mathrm{C}$ ) under conditions of $0.5 \% \mathrm{~N}_{2} \mathrm{O}$, balance $\mathrm{He}$ and a GHSV of $7500 \mathrm{~h}^{-1}$ [29]. The high activity of the catalysts prepared by Kumar et al. was associated to the enhanced redox properties due to the ratio of $\mathrm{Mn}^{4+/ 3+}$ and the resulting charge compensation effect due to the substitution of $\mathrm{Ba}$ into the A site. Previously we have shown it is possible to achieve a $\mathrm{T}_{50}$ of $410{ }^{\circ} \mathrm{C}\left(\mathrm{N}_{2} \mathrm{O}\right.$ decomposition rate of $32 \mathrm{~mol} \mathrm{~h}^{-1} \mathrm{~kg}^{-1}$ at $450{ }^{\circ} \mathrm{C}$ ) using a $\operatorname{Pr}_{0.75} \mathrm{Ba}_{0.25} \mathrm{CoO}_{3}$ catalyst, prepared by supercritical anti-solvent precipitation [33]. The catalysts prepared by Kumar et al. and Hutchings and co-workers are amongst the most active perovskites for $\mathrm{N}_{2} \mathrm{O}$ decomposition reported in the literature to date.

In this work we investigate the controlling factors for preparing a perovskite catalyst for $\mathrm{N}_{2} \mathrm{O}$ decomposition. Surface area, redox capabilities, oxygen mobility, A and B site elements, and $\mathrm{Co}-\mathrm{O}$ bond strength are all investigated. The rate-limiting step in the decomposition of $\mathrm{N}_{2} \mathrm{O}$ is typically the recombination of oxygen on the active site [34-40], if the proximity of the atomic oxygen species is greater than the interaxial distance of oxygen then the bond is unlikely to form and be desorbed as molecular oxygen, therefore blocking an active site [41, 42]. However, if the $\mathrm{Co}-\mathrm{O}$ bond is weak, the mobility of the oxygen can be improved as it is more able to move around the surface of the catalyst and can recombine with surface oxygen, regenerating the active site. Therefore, producing a catalyst with a relatively weak $\mathrm{Co}-\mathrm{O}$ bond is advantageous. Here, we have shown that this is the case in the most active catalysts by use of $\mathrm{H}_{2}$-TPR. $\mathrm{H}_{2}$-TPR and $\mathrm{O}_{2}$-TPD have been used to confirm the presence of redox properties, including highly mobile oxygen species. The resulting low $\mathrm{T}_{50}$ of $448{ }^{\circ} \mathrm{C}\left(\mathrm{N}_{2} \mathrm{O}\right.$ decomposition rate $22.8 \mathrm{~mol} \mathrm{~h}^{-1} \mathrm{~kg}^{-1}$ at $450{ }^{\circ} \mathrm{C}$ ), highlights the need for careful catalyst design to maximise the decomposition rate.

\section{Experimental}

\subsection{Catalyst Preparation}

\subsubsection{Citric Acid Preparation Method}

Benchmark perovskite based catalysts were prepared by citric acid preparation as described by Fierro et al. [43]. Metal nitrates were dissolved in deionised water $(50 \mathrm{~mL})$ while stirring at $50{ }^{\circ} \mathrm{C}$ in a round bottom flask. Citric acid (Sigma Aldrich, $>99.95 \%$ ) (metal:citric acid $=1: 2$ molar ratio) was added to the solution and the temperature increased to $90^{\circ} \mathrm{C}$. After 30 min the temperature was increased to $110^{\circ} \mathrm{C}$ and stirred for $16 \mathrm{~h}$ to give a dry powder. Following grinding, all catalysts were pre-treated in an oven at $>200{ }^{\circ} \mathrm{C}$ (details given in Table 3) with a ramp rate of $1{ }^{\circ} \mathrm{C} \mathrm{min}^{-1}$ to ensure citric acid combustion, as indicated by TGA. These materials were calcined in flowing air at a suitable temperature, for $3 \mathrm{~h}$ at $1{ }^{\circ} \mathrm{C} \min ^{-1}$ to form a pure phase perovskite, as determined by in situ X-ray diffraction (XRD).

\subsubsection{Oxalic Acid Preparation Method}

Perovskite catalysts with enhanced phase purity were prepared using oxalic acid as a precipitation agent, based on the work by Fan et al. [44]. Metal nitrates were added in the appropriate ratios totalling $0.02 \mathrm{~mol}$ of metal to ethanol (200 mL, Sigma Aldrich, 99.8\%) and stirred. Once the metal salts were dissolved, oxalic acid (0.024 mol, Sigma Aldrich, >99\%) was added and the solution was aged for $2 \mathrm{~h}$ at room temperature. After aging, the solution was filtered and washed with ethanol $(500 \mathrm{~mL})$ and $\operatorname{dried}\left(110^{\circ} \mathrm{C}, 16 \mathrm{~h}\right)$. The resulting solid was pre-treated at $300{ }^{\circ} \mathrm{C}$, followed by calcination in flowing air at a suitable temperature to form a pure phase perovskite, as determined by in situ XRD.

\subsubsection{Supercritical Anti-Solvent (SAS) Preparation Method}

Perovskite catalysts were prepared using the supercritical anti-solvent (SAS) precipitation method is based on a method previously reported [45-48]. A mixture of metal acetylacetonate hydrate and acetate precursor salts were dissolved in ethanol (Sigma Aldrich 99.8\%) together with 5\% deionised water. SAS experiments were performed using apparatus manufactured by Separex. $\mathrm{CO}_{2}(99.99 \%$, BOC) was pumped through the system (held at $150 \mathrm{bar}, 40^{\circ} \mathrm{C}$ ) via the outer part of a co-axial nozzle at a rate of $12 \mathrm{~kg} \mathrm{~h}^{-1}$ $(41 \mathrm{~Hz})$. The metal salt solution was concurrently pumped through the inner nozzle using an Agilent HPLC pump at a rate of $4 \mathrm{~mL} \mathrm{~min}{ }^{-1}$. At this point, the solvent rapidly solubilises into the surrounding supercritical $\mathrm{CO}_{2}$, causing 
the precipitation of the metal precursors. This was recovered on a stainless-steel frit, while the $\mathrm{CO}_{2}$-solvent mixture passed downstream, where the pressure was decreased to separate the solvent and $\mathrm{CO}_{2}$. Precipitation was carried out for $120 \mathrm{~min}$ followed by a purge of the system with $\mathrm{CO}_{2}$ for $1 \mathrm{~h}$ under $150 \mathrm{bar}$ and $40{ }^{\circ} \mathrm{C}$. The system was then depressurised, and the dry powder collected. The resulting SAS precipitates were then pre-treated at $300{ }^{\circ} \mathrm{C}$, followed by calcination in flowing air at a suitable temperature to form a pure phase perovskite, as determined by in situ XRD.

\section{$2.2 \mathrm{~N}_{2} \mathrm{O}$ decomposition}

All reactions were performed at atmospheric pressure in a continuous-flow fixed-bed reactor. A reactor tube $(4.6 \mathrm{~mm}$ internal diameter, stainless steel) was packed with catalyst $(0.0625 \mathrm{~g})$ between two layers of quartz wool. Reactions were performed over the temperature range of $200-600{ }^{\circ} \mathrm{C}$, with a flow rate of $100 \mathrm{~mL} \mathrm{~min}^{-1}$ (GHSV: in the range of 35,000 to $40,000 \mathrm{~h}^{-1}$ ). The gas feed was composed of $1 \%$ $\mathrm{N}_{2} \mathrm{O} / \mathrm{He}$. All outgoing gaseous products were analysed online using an Agilent 7890B Gas Chromatograph (GC) (columns: Hayesep Q (80-100 mesh, $1.8 \mathrm{~m}$ ) MolSieve 5A (80-100 mesh, $2 \mathrm{~m}$ ) fitted with a thermal conductivity detector.

The $\mathrm{N}_{2} \mathrm{O}$ decomposition rate at a given temperature $\left(\mathrm{mol}_{\mathrm{N} 2 \mathrm{O}} \mathrm{h}^{-1} \mathrm{~kg}_{\text {cat }}{ }^{-1}\right.$ shortened to $\left.\mathrm{mol} \mathrm{h}^{-1} \mathrm{~kg}^{-1}\right)$ is given by the equation:

Conversion at given temperature $(\%) \times$ Flow rate of $\mathrm{N}_{2} \mathrm{O}\left(\mathrm{mol} \mathrm{h}^{-1}\right)$ Catalyst weight $(\mathrm{kg})$

\subsection{Catalyst characterisation}

X-ray photoelectron spectroscopy (XPS) was performed on a Thermo Fisher Scientific K-alpha ${ }^{+}$spectrometer. Samples were analysed using a micro-focused monochromatic Al X-ray source $(72 \mathrm{~W})$ over an area of approximately 400 microns. Data was recorded at pass energies of $150 \mathrm{eV}$ for survey scans and $40 \mathrm{eV}$ for high resolution scan with $1 \mathrm{eV}$ and $0.1 \mathrm{eV}$ step sizes respectively. Charge neutralisation of the sample was achieved using a combination of both low energy electrons and argon ions. Data analysis was performed in CasaXPS using a Shirley type background and Scofield cross sections, with an energy dependence of $-0.6 \mathrm{eV}$.

Powder X-ray Diffraction (XRD) analysis was performed on a PANalytical X'Pert Pro diffractometer using a Ni-filtered $\mathrm{CuK} \alpha$ radiation source operating at $40 \mathrm{kV}$ and $40 \mathrm{~mA}$. Standard analysis was performed using a $40 \mathrm{~min}$ run with a back filled sample holder. Patterns were identified using the International Centre for Diffraction Data Powder
Diffraction File. Perovskite phase purity was determined using the International Centre for Diffraction Database (ICDD). Phases were assigned using the 'search and match' function in X'Pert Highscore software. Phase identification is performed by comparing the X-Ray diffraction pattern with known reference data in the ICDD. When two or more phases are present it is possible to achieve a percentage of each, the software uses the information the powder diffraction file (PDF) associated to produce the values, this is semiquantitative and the technique that has been used in this manuscript. It was assumed that no amorphous regions were present due to the high calcination temperatures used.

In situ XRD was performed using a PANalytical X'Pert Pro diffractometer using a $\mathrm{Ni}$-filtered $\mathrm{CuK} \alpha$ radiation source operating at $40 \mathrm{kV}$ and $40 \mathrm{~mA}$, fitted with a cell that allows temperature control and gas flow using Bronkhorst mass flow controllers. Characterisation was controlled via software, the 'Data collector' program was used to set temperature, run time and repeats measurements. Patterns were identified using the International Centre for Diffraction Data Powder Diffraction File.

Thermogravimetric Analysis (TGA) was performed using a Perkin Elmer TGA 4000, with $10 \mathrm{mg}$ sample with $50 \mathrm{~mL} \mathrm{~min}^{-1}$ air and a ramp rate of $5{ }^{\circ} \mathrm{C} \mathrm{min}{ }^{-1}$, from 30 to $800{ }^{\circ} \mathrm{C}$. Mass losses were recorded as changes in $\mathrm{mg}$ and converted into a percentage of the total mass of the sample. The metal precursors along with precipitating agents used in this study were analysed to determine their decomposition temperatures, the mass loss profiles are shown in Fig. $\mathrm{S} 1 \mathrm{a}-\mathrm{j}$. Due to the ramp rate of $5{ }^{\circ} \mathrm{C} \mathrm{min}^{-1}$ there is likely to be a delay of $\pm 20^{\circ} \mathrm{C}$ to the final decomposition event when compared to a calcination that is held at a temperature. The secondary profile given with dashed lines in the TGA profile are the derivative of temperature.

Oxygen Temperature Programmed Desorption $\left(\mathrm{O}_{2}-\mathrm{TPD}\right)$ profiles were performed using a ChemBET TPR/TPD equipped with a TCD to monitor oxygen evolution. A pretreatment in $\mathrm{He}$ up to $550{ }^{\circ} \mathrm{C}$ was performed, followed by doping of oxygen using $10 \% \mathrm{O}_{2} / \mathrm{He}$ at $550{ }^{\circ} \mathrm{C}$, the sample was cooled to room temperature and the gas changed to $\mathrm{He}$, followed by desorption of oxygen up to $850{ }^{\circ} \mathrm{C}$ at $10{ }^{\circ} \mathrm{C} \mathrm{min}{ }^{-1}$ and held for $10 \mathrm{~min}$ at $\mathrm{T}_{\max }$, using an attenuation of 2, TCD sensitivity of 150 and flow $30 \mathrm{~mL} \mathrm{~min}^{-1}$. The sample mass was typically $60 \mathrm{mg}$.

Nitrogen adsorption isotherms were collected using a Quantachrome Quadrasorb evo. A 20-point analysis was performed using $\mathrm{N}_{2}$ as the adsorbate gas. Samples were degassed for $14 \mathrm{~h}$ at $300{ }^{\circ} \mathrm{C}$ prior to analysis. Analysis was carried out at $-196{ }^{\circ} \mathrm{C}$ with $\mathrm{P}_{0}$ measured continuously. Free space was measured post analysis with $\mathrm{He}$. The data was analysed using the BET method.

TPR was performed using a ChemBET TPR/TPD equipped with a TCD to monitor hydrogen uptake. A 
pre-treatment in $\mathrm{He}$ up to $150{ }^{\circ} \mathrm{C}$ was performed, followed by a reduction in $10 \% \mathrm{H}_{2} / \mathrm{Ar}$ up to $800{ }^{\circ} \mathrm{C}$, held for $30 \mathrm{~min}$ at $\mathrm{T}_{\max }$, using an attenuation of 4, TCD sensitivity of 150 and flow $15 \mathrm{~mL} \mathrm{~min}^{-1}$. The sample mass used was typically between 40 and $50 \mathrm{mg}$.

MP-AES was carried out using an Agilent 4100 MP-AES utilising Agilent MP expert software. Calibration samples were prepared by dilution of a standard metal solution with deionised water. A minimum of 4 calibration plots were used per analysis. Solid catalyst samples $(50 \mathrm{mg})$ were dissolved in aqua regia ( $4 \mathrm{~mL}$ diluted to $50 \mathrm{~mL}$ with deionised water) to give a pre-calculated approximate metal concentration.

\section{Results and Discussion}

Initially, two $\mathrm{Sr}_{\mathrm{x}} \mathrm{Co}_{\mathrm{y}} \mathrm{M}_{\mathrm{z}}$-based perovskite materials (where $\mathrm{M}=\mathrm{La}$ or $\mathrm{Fe}$ ) were prepared by a sol-gel method with citric acid, as previously reported [43, 49-55]. $\mathrm{La}_{0.75} \mathrm{Sr}_{0.25} \mathrm{CoO}_{x}$ (denoted LSC) and $\mathrm{SrCo}_{0.81} \mathrm{Fe}_{0.19} \mathrm{O}_{\mathrm{x}}$ (denoted SCF) were prepared by the combination of citric acid and metal nitrates using a molar ratio of 2:1. Citric acid combustion occurs between 150 and $200^{\circ} \mathrm{C}$, as highlighted in the thermal analysis of LSC (Fig. 1a), with a rapid weight loss at $170{ }^{\circ} \mathrm{C}$. This is also accompanied by the decomposition of La nitrate, followed by further weight losses at $300{ }^{\circ} \mathrm{C}$ due La and Co nitrate decomposition with a final decomposition event seen at $600{ }^{\circ} \mathrm{C}$ due to the decomposition of Sr nitrate. To form a pure phase perovskite, the catalyst precursor was treated at an appropriate temperature, as determined by in situ XRD. When performing in situ XRD, the sample must be packed into a sample holder; it is crucial that when the sample is heated, the sample remains flat and the holder fully packed to ensure that the incidence angle of the X-rays remain consistent. Therefore, the catalyst must be pre-treated to limit mass loss when obtaining in situ XRD patterns. For this catalyst, $400{ }^{\circ} \mathrm{C}$ was chosen as the precursor has mostly decomposed below this point; $70 \%$ of the catalyst mass had been lost (Fig. 1a).

From the in situ XRD of LSC given in Fig. 1b it is possible to see the growth of the principal perovskite phase via the reflection at $34^{\circ} 2 \theta$ as the temperature increases from 550 to $850{ }^{\circ} \mathrm{C}$. At $850{ }^{\circ} \mathrm{C}$ the perovskite phase was $98 \%$ pure, with a reflection seen due to the presence of $\mathrm{CoO}$. This temperature was selected as a suitable calcination temperature, due to the extended length of time the sample was held at the maximum temperature, consequently the purity should increase. This temperature was also deemed suitable from the TGA profile (Fig. 1a) as all major decomposition events had occurred prior to this.

The TGA profile of SCF is given in Fig. 2a, where two decomposition events below $350^{\circ} \mathrm{C}$ were noted and ascribed to the decomposition of $\mathrm{Co}$ and Fe nitrates, and the citrate precursor. The final mass loss was due to the decomposition of Sr nitrate. $550{ }^{\circ} \mathrm{C}$ was determined as a suitable pre-treatment temperature prior to performing in situ XRD analysis. The in situ XRD of SCF given in Fig. 2b illustrates the profile changes over the temperature range of 550 to $850{ }^{\circ} \mathrm{C}$. Here, small differences can be observed as the temperature increases from 550 to $800{ }^{\circ} \mathrm{C}$ with a reduction of the reflections present at 24,26 and $36.5^{\circ}$. This is paired with the formation of new reflections, most notably at 32 and $27^{\circ}$, that are present in the final material at $850{ }^{\circ} \mathrm{C}$. A pure phase SCF perovskite is not formed at $850{ }^{\circ} \mathrm{C}$ as a $\mathrm{Co}_{3} \mathrm{O}_{4}$ impurity is formed during the heat treatment. Therefore, a higher calcination temperature of $900{ }^{\circ} \mathrm{C}$ was required (the maximum operating temperature of the furnaces), resulting in a perovskite phase purity of $81 \%$.

XRD of the final calcined perovskite structures of LSC and SCF are shown in Fig. S2. SCF contains three reflections

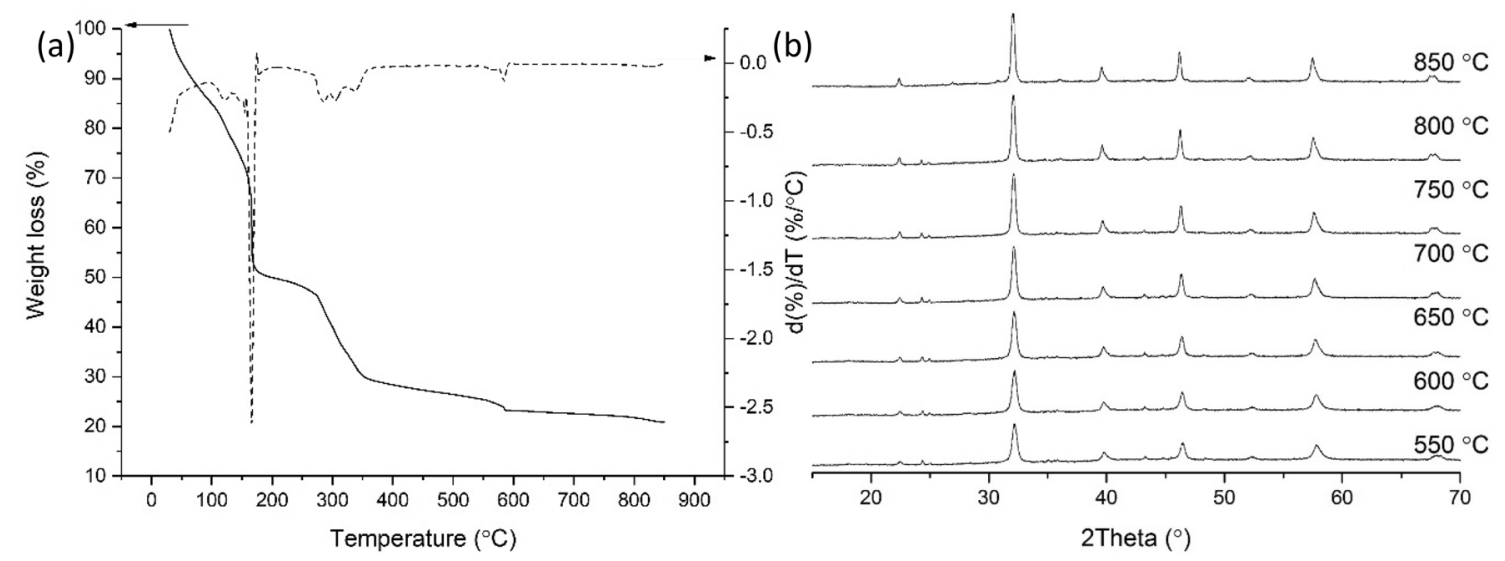

Fig. 1 a TGA of LSC up to $850{ }^{\circ} \mathrm{C}$ at $5{ }^{\circ} \mathrm{C} \mathrm{min}^{-1}$ in air at $50 \mathrm{~mL} \mathrm{~min}{ }^{-1}$. The secondary profile given with dashed lines in the TGA profile are the derivative of temperature. $\mathbf{b}$ In situ XRD of LSC treated to $400{ }^{\circ} \mathrm{C}$ prior to analysis heated from 550 to $850{ }^{\circ} \mathrm{C} \mathrm{in} \mathrm{air}\left(25 \mathrm{~mL}\right.$ min $\left.{ }^{-1}\right)$ 


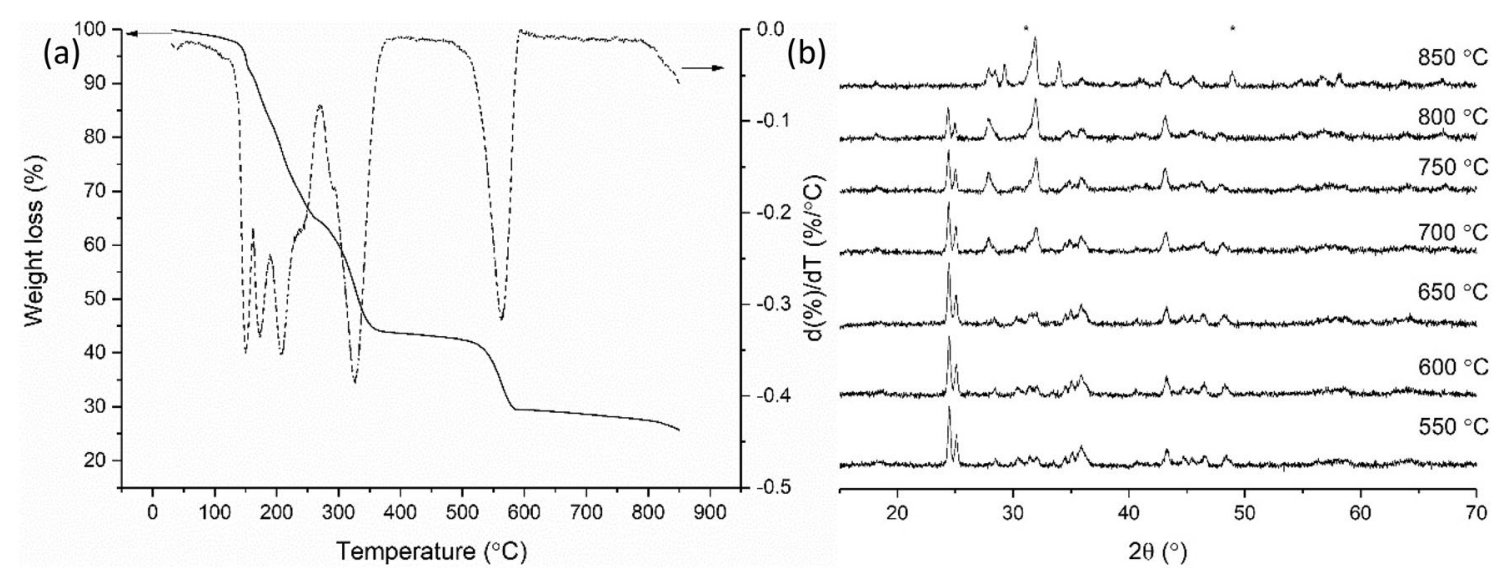

Fig. 2 a TGA of SCF up to $850{ }^{\circ} \mathrm{C}$ at $5{ }^{\circ} \mathrm{C} \min ^{-1}$ in air at $50 \mathrm{~mL} \mathrm{~min}^{-1}$. The secondary profile given with dashed lines in the TGA profile are the derivative of temperature. $\mathbf{b}$ In situ XRD of SCF

at $18.5,36.8$ and $65.6^{\circ}(2 \theta)$ due to the presence of $\mathrm{a} \mathrm{Co}_{3} \mathrm{O}_{4}$ impurity, whereas LSC contains one reflection at $36.7^{\circ}(2 \theta)$ due to the presence of a $\mathrm{CoO}$ impurity. All other reflections are due to the perovskite structure.

Analysis of the O $1 s$ region in XPS gives an indication of the species of oxygen present on the surface of the catalyst. There are four notable oxygen species typically observed for perovskite oxides: lattice oxygen $\left(\mathrm{O}^{2-}\right)$ from lanthanide elements $(528.6 \mathrm{eV})$ [56-59], lattice oxygen species due to $\mathrm{Co} / \mathrm{Fe}$ (ca. 529.5 eV) [60-63], surface hydroxyl species $\left(\mathrm{OH}^{-}\right)$at $531.0 \mathrm{eV}$ [64], and a species at $533.0 \mathrm{eV}$, typically ascribed to water [65-67]. The water is trapped within the lattice, rather than being physisorbed on the surface as this would be removed under the ultra-high vacuum conditions required for XPS, unless the surface is hygroscopic, some adsorbed water can remain. Lattice oxygen is also referred treated to $400{ }^{\circ} \mathrm{C}$ prior to analysis heated from 550 to $850{ }^{\circ} \mathrm{C}$ in air $\left(25 \mathrm{~mL} \mathrm{~min}^{-1}\right)$, *Marks $\mathrm{Co}_{3} \mathrm{O}_{4}$ impurity

to as $\beta$-oxygen, and oxygen vacancies are referred to as $\alpha$-oxygen [26, 68].

The O $1 s$ region of the spectra of LSC (Fig. 3) shows all four species of oxygen present. Most notably the lanthanide lattice oxygen species made up a large proportion, $c a$. $42 \%$ of the $\mathrm{O} 1 s$ region. The rest were lattice oxygen from transition metal species and hydroxyl species (breakdown provided in Table S2). Conversely, for the SCF catalyst this is drastically different; lattice oxygen makes up just $1 \%$ of the observed oxygen species (Fig. 3). The surface does not contain these lattice oxygen species, instead the carbon region indicates that the surface contains a thin layer of carbonate species that could have formed when $\mathrm{Sr}$ came into contact with the atmosphere $[69,70]$. There is a large peak at $531 \mathrm{eV}$ in the $\mathrm{O} 1 s$ spectra that can either be a contribution from hydroxyl $\mathrm{OH}^{-}$or carbonate $\mathrm{CO}_{3}{ }^{2-}$ species. To determine

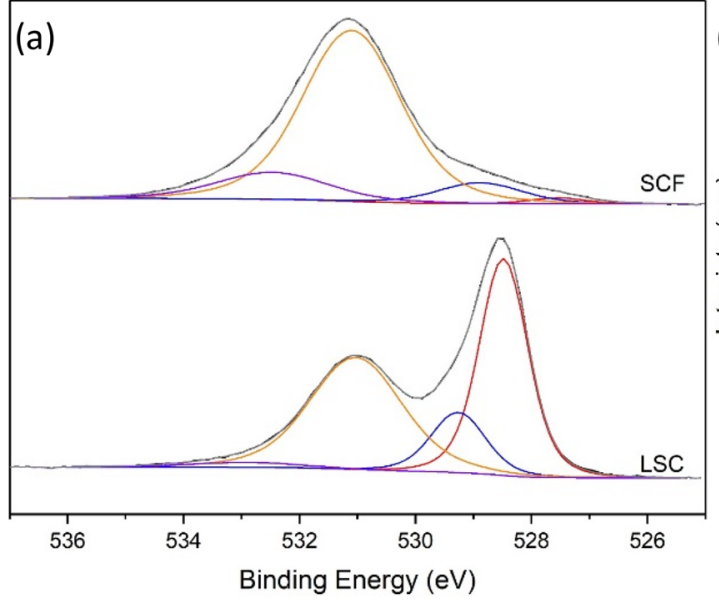

Fig. 3 a XPS O $1 s$ region of LSC and SCF catalysts Fittings: redlattice $\mathrm{O}^{2-}$, blue-lattice $\mathrm{O}^{2-}$ transition metal, orange-hydroxyl species $\mathrm{OH}^{-}$or $\mathrm{CO}_{3}{ }^{2-}$ (majority $\mathrm{CO}_{3}{ }^{2-}$ in $\mathrm{SCF}$ ), and purple-molecular

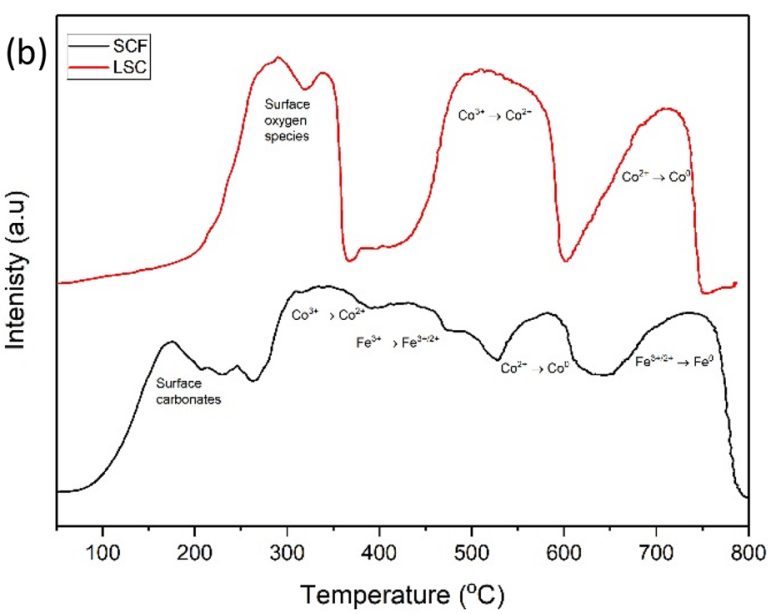

water on surface. $\mathbf{b ~ \mathrm { H } _ { 2 }}$-TPR of LSC and SCF catalysts, performed at $5{ }^{\circ} \mathrm{C} \mathrm{min}{ }^{-1}$ up to $800{ }^{\circ} \mathrm{C}$, under a flow of $10 \% \mathrm{H}_{2} / \mathrm{Ar}$ 
which species is present, the carbon region must be studied. If a peak is present at $289.4 \mathrm{eV}$ this is due to the presence of carbonate. In the case of SCF the contribution is from a carbonate species, as confirmed by the carbon spectra shown in Fig. S3 [71]. The LSC perovskite has a small insignificant peak in the carbon region indicating that the oxygen species present is mainly $\mathrm{OH}^{-}$. The lanthanum $3 \mathrm{~d}$ XPS spectra (Fig. S4) shows that all lanthanum containing catalysts have both lanthanum oxide and lanthanum carbonate present. This explains why the LSC catalyst has a small peak at $289.4 \mathrm{eV}$, without having a large contribution from strontium carbonate. This is further confirmed by the comparison of the $\mathrm{C} 1 \mathrm{~s}$ peak at $289 \mathrm{eV}$ and $\mathrm{O} 1 \mathrm{~s}$ peak at $531 \mathrm{eV}$ discussed later in the manuscript. The $\mathrm{Sr}$ carbonate species is hygroscopic, as indicated by the large peak assigned to molecular water on the surface at $533 \mathrm{eV}, c a .14 \%$ of the O 1 s spectra. Notably, the oxide of $\mathrm{Sr}$ is found at a slightly lower binding energy than other elements, with a response seen at $527 \mathrm{eV}[72,73]$. The lack of lattice oxygen observed may be a result of the surface sensitive nature of XPS with an analysis depth of $c a$. 8-10 nm. Therefore, an abundance of lattice oxygen in the bulk will not be represented. Additionally, the presence of the carbonate on the surface would limit the ability to detect the lattice oxygen in the bulk. The presence of the carbonate is expected to limit the catalytic activity of the perovskite.

The $\mathrm{H}_{2}$-TPR profile can indicate the reducibility of the perovskites, where the reducibility is linked to its ability to release oxygen from the perovskite structure by reacting with $\mathrm{H}_{2} \cdot \mathrm{H}_{2}$-TPR also gives an indication to the strength of the Co-O bond: the weaker the bond the more mobile the oxygen species, and the lower the Co reduction temperature [74]. The reduction of surface-adsorbed $\mathrm{O}$ species or nonstoichiometric excess oxygen reduction of oxygen species, this can include oxygen adsorbed on the oxygen deficiency, take place between 200 and $300{ }^{\circ} \mathrm{C}[75,76]$. This is followed by the step-wise reduction of $\mathrm{Co}^{3+}$ to $\mathrm{Co}^{2+}$ between 200 and $360{ }^{\circ} \mathrm{C}$ and $\mathrm{Co}^{2+}$ to $\mathrm{Co}^{0}$ between 450 and $540{ }^{\circ} \mathrm{C}[77,78]$. $\mathrm{Fe}$ is the only other reducible metal in these catalysts, both $\mathrm{La}$ and $\mathrm{Sr}$ are not reducible under the conditions studied [79, 80]. Fe reduction takes place in the following steps: $\mathrm{Fe}^{3+}$ to $\mathrm{Fe}^{3+/ 2+}$ at $c a .300^{\circ} \mathrm{C}$, followed by the reduction of $\mathrm{Fe}^{3+/ 2+}$ to $\mathrm{Fe}^{0}$ at around $700{ }^{\circ} \mathrm{C}$ [81]. The $\mathrm{H}_{2}$-TPR of LSC and SCF are shown in Fig. 3b, SCF shows the initial reduction of surface oxygen species and carbonates $\left(<250{ }^{\circ} \mathrm{C}\right)$, followed by the simultaneous reduction of $\mathrm{Co}^{3+}$ to $\mathrm{Co}^{2+}$ and $\mathrm{Fe}^{3+}$ to $\mathrm{Fe}^{3+/ 2+}$ between 300 and $500{ }^{\circ} \mathrm{C}$, followed by the reduction of $\mathrm{Co}^{2+}$ to $\mathrm{Co}^{0}$ between 500 and $600{ }^{\circ} \mathrm{C}$, with the final step due to the reduction of $\mathrm{Fe}^{3+/ 2+}$ to $\mathrm{Fe}^{0}$ between 650 and $790{ }^{\circ} \mathrm{C}$. The $\mathrm{H}_{2}$-TPR of LSC is more difficult to interpret as the reduction temperatures are far higher than expected. The reduction of surface oxygen species takes place between 200 and $350{ }^{\circ} \mathrm{C}$ followed by the reduction of $\mathrm{Co}^{3+}$ to $\mathrm{Co}^{2+}$ between 450 and $600{ }^{\circ} \mathrm{C}$, followed by the final reduction of $\mathrm{Co}^{2+}$ to
$\mathrm{Co}^{0}$ between 600 and $750{ }^{\circ} \mathrm{C}$. As the reduction of Co in LSC and SCF takes place at the expected temperatures the $\mathrm{Co}-\mathrm{O}$ bond strength would be anticipated to be intermediate.

Table 2 contains the surface area data for the LSC and $\mathrm{SCF}$, with LSC having the highest $\left(15 \mathrm{~m}^{2} \mathrm{~g}^{-1}\right)$. This is likely a result of a lower calcination temperature, as higher calcination temperatures can lead to lower surface areas $[16,17$, $43,82,83]$. This is apparent with the SCF catalyst, which was calcined at $900{ }^{\circ} \mathrm{C}$, and has a surface area of $7 \mathrm{~m}^{2} \mathrm{~g}^{-1}$, however the perovskite is not $100 \%$ pure, $\mathrm{a} \mathrm{Co}_{3} \mathrm{O}_{4}$ phase is also present that can have different textural properties The temperature required for $50 \%$ conversion of $\mathrm{N}_{2} \mathrm{O}\left(\mathrm{T}_{50}\right)$ over the LSC catalyst is $468{ }^{\circ} \mathrm{C}$, compared to $585^{\circ} \mathrm{C}$ over the SCF catalyst (Fig. 4). The lower activity of the SCF catalyst indicates that lattice oxygen species are crucial for the decomposition of $\mathrm{N}_{2} \mathrm{O}$ (Fig. 4). This is due to $\mathrm{N}_{2} \mathrm{O}$ adsorption taking place at a vacant site, such as a coordinatively unsaturated metal, followed by decomposition and release of $\mathrm{N}_{2}$, with adsorbed $\mathrm{O}$. The rate-limiting step of this reaction is the recombination of oxygen [34, 35], therefore, a high lattice oxygen concentration with sufficient mobility can aid this reaction step and produce a more active catalyst. In the case of SCF, the phase impurities present have a negative impact on the activity, with temperatures greater than $600{ }^{\circ} \mathrm{C}$ required for significant conversion.

\subsection{Citric Acid Preparation of $\mathrm{La}_{0.75} \mathrm{Sr}_{0.25} \mathrm{CO}_{0.81} \mathrm{Fe}_{0.19} \mathrm{O}_{\mathrm{x}}$ (LSCF Citric)}

Based on the reaction data shown in Fig. 4 and catalyst characterisation data from Table 2, it is apparent that higher surface area, phase purity and lattice oxygen concentration lead to a more active catalyst. Therefore, the two perovskite metal ratios were combined with the idea that introducing secondary metals into both the A and B site would facilitate redox coupling and allow for a lower calcination temperature to form a pure phase perovskite resulting in a higher surface area and subsequently an increase in activity.

Table 2 Calcination temperature, specific surface area, phase purity, lattice oxygen percentage and the temperature required for $50 \%$ conversion $\left(\mathrm{T}_{50}\right)$

\begin{tabular}{llllll}
\hline Catalyst & $\begin{array}{l}\text { Perovskite } \\
\text { phase } \\
\text { purity }(\%)^{\mathrm{a}}\end{array}$ & $\begin{array}{l}\text { Calcination } \\
\text { tempera- } \\
\text { ture }\left({ }^{\circ} \mathrm{c}\right)\end{array}$ & $\begin{array}{l}\text { Specific } \\
\text { surface } \\
\text { area }\left(\mathrm{m}^{2}\right. \\
\left.\mathrm{g}^{-1}\right)\end{array}$ & $\mathrm{T}_{50}\left({ }^{\circ} \mathrm{C}\right)$ & $\begin{array}{l}\text { Surface } \\
\text { lattice O } \\
(\%)^{\mathrm{b}}\end{array}$ \\
\hline LSC & 98 & 850 & 15 & 468 & 42 \\
SCF & 81 & 900 & 7 & 585 & 1 \\
\hline
\end{tabular}

a Perovskite phase purity calculated using XRD diffraction pattern and the ratio between the single perovskite phase and any impurities.

${ }^{b}$ Lattice oxygen calculated by the ratio of lattice oxygen species to the sum of molecular water, transition metal lattice oxygen, hydroxyl species, as derived from XPS measurements. 
Fig. 4 Graph showing $\mathrm{N}_{2} \mathrm{O}$ decomposition using perovskite-based catalysts. Reaction Conditions: $1 \% \mathrm{~N}_{2} \mathrm{O} / \mathrm{He}$, total flow $100 \mathrm{~mL} \mathrm{~min}^{-1}$. Legend: filled square- $\mathrm{SCF}$, filled circle-LSC. If error bars are not present, then smaller than symbol and less than $1 \%$

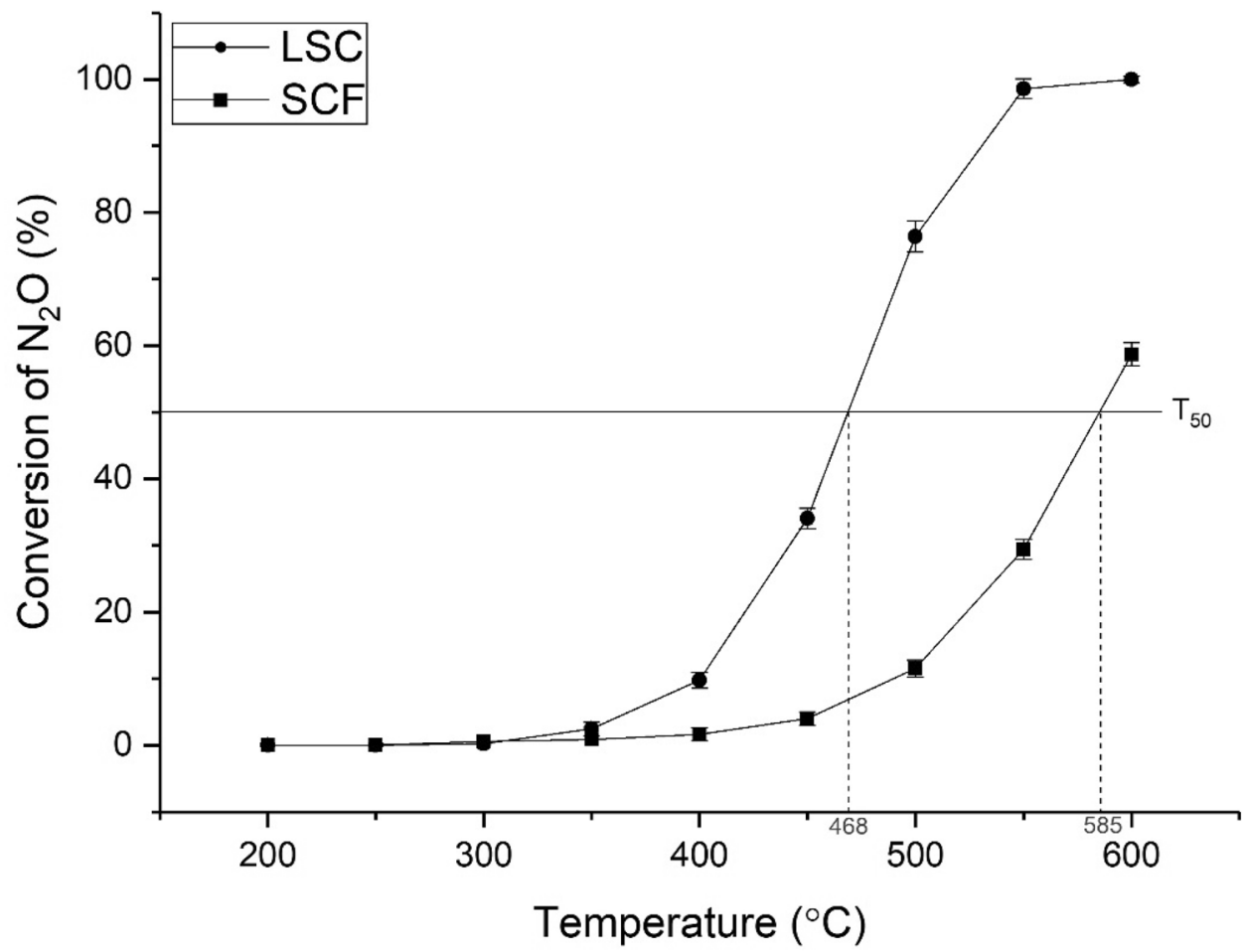

A $\mathrm{La}_{0.75} \mathrm{Sr}_{0.25} \mathrm{Co}_{0.81} \mathrm{Fe}_{0.19} \mathrm{O}_{\mathrm{x}}$ perovskite was prepared by the citric acid precipitation method and henceforth referred to as LSCF citric.

Optimisation of the perovskite final calcination temperature was performed using TGA and in situ XRD as detailed previously, the details are provided in the SI. A final calcination temperature of $550{ }^{\circ} \mathrm{C}$ was deemed appropriate.

Previous reports suggest that a high surface area perovskite will lead to an active $\mathrm{N}_{2} \mathrm{O}$ decomposition catalyst $[8,15$, 84]. The specific surface area of the LSCF citric perovskite was measured at $13 \mathrm{~m}^{2} \mathrm{~g}^{-1}$ which is comparable to the LSC citric material $\left(15 \mathrm{~m}^{2} \mathrm{~g}^{-1}\right)$. Most attempts at increasing the surface area of perovskites have found success through supporting perovskites on high surface area supports. Alini et al. supported a $\mathrm{CaMn}_{0.6} \mathrm{Cu}_{0.4} \mathrm{O}_{3}$ perovskite on a $\mathrm{CeO}_{2}-\mathrm{ZrO}_{2}$ support [84]. The surface area of this catalyst increased from 15 to $63 \mathrm{~m}^{2} \mathrm{~g}^{-1}$, with a $10 \%$ perovskite loading, the increase in surface area was due to the presence of the $\mathrm{CeO}_{2}-\mathrm{ZrO}_{2}$ support that the perovskite was dispersed on The $\mathrm{N}_{2} \mathrm{O}$ conversion over the catalyst increased from 58 to $67 \%$ at $500{ }^{\circ} \mathrm{C}$. The authors linked both the increase in surface area and the contribution of the support's oxygen mobility to the increase in observed activity [84]. However, Dacquin et al. reported that it was possible to increase the surface area of a $\mathrm{LaCoO}_{3}$ from 12 to $50 \mathrm{~m}^{2} \mathrm{~g}^{-1}$ by changing the preparation method from templating to reactive grinding. [85] It was stated that the highest surface area catalysts were the most active for $\mathrm{N}_{2} \mathrm{O}$ decomposition despite the phases of the perovskite present remaining constant between preparation methods. Therefore the increase in activity was ascribed to the increases in specific surface area and the higher density of oxygen vacancies present [85].

\subsection{Supercritical Anti-Solvent Precipitation: $\mathrm{La}_{0.75} \mathrm{Sr}_{0.25} \mathrm{Co}_{0.81} \mathrm{Fe}_{0.19} \mathrm{O}_{\mathrm{x}}$ (LSCF SAS)}

Previously, we have shown that the surface area of a perovskite can be significantly increased via a (SAS) preparation method [33]. A $\mathrm{La}_{0.75} \mathrm{Sr}_{0.25} \mathrm{Co}_{0.81} \mathrm{Fe}_{0.19} \mathrm{O}_{\mathrm{x}}$ (LSCF SAS) perovskite was prepared by SAS, the appropriate calcination temperature was determined by TGA and in situ XRD as $800{ }^{\circ} \mathrm{C}$, further details are provided in the SI. As such a high temperature is required for calcination $\left(800^{\circ} \mathrm{C}\right)$, which resulted in a specific surface area of $12 \mathrm{~m}^{2} \mathrm{~g}^{-1}$. An XRD measurement was performed at room temperature after calcination at $800{ }^{\circ} \mathrm{C}$ and confirmed a single rhombohedral phase present.

\subsection{Oxalic Acid Precipitation Method $\mathrm{La}_{0.75} \mathrm{Sr}_{0.25} \mathrm{Co}_{0.81} \mathrm{Fe}_{0.19} \mathrm{O}_{\mathrm{x}}$ (LSCF Oxalic)}

To further investigate the effect of surface area, purity and lattice oxygen concentration on the activity of perovskite catalysts for $\mathrm{N}_{2} \mathrm{O}$ decomposition, the LSCF perovskite was prepared using an oxalic acid-based method. Oxalic acid facilitates the formation of a metal oxalate network, which then collapses to form a well dispersed metal oxide [33, 44, $86,87]$. In situ XRD and TGA were used to determine a 
suitable calcination temperature of $750{ }^{\circ} \mathrm{C}$, further details are provided in the SI. An XRD measurement was performed after calcination and confirmed a single-phase present, confirming the rhombohedral structure. The final structure of all LSCF perovskites are shown in Fig. S7, LSCF is not restricted to one structure, as both a rhombohedral and cubic structure are noted. The specific surface area of the LSCF oxalic sample was calculated to be $14 \mathrm{~m}^{2} \mathrm{~g}^{-1}$ following nitrogen adsorption experiments.

\section{Discussion}

The LSCF perovskite samples were used as catalysts for the decomposition of $\mathrm{N}_{2} \mathrm{O}$ and compared to the activity of the ternary perovskite materials as illustrated in Fig. 4. LSCF citric demonstrated higher activity than both the original LSC and SCF catalysts, with a $\mathrm{T}_{50}$ of $448{ }^{\circ} \mathrm{C}$ (Table 3), this is a decrease from $468{ }^{\circ} \mathrm{C}$ (LSC) and $585^{\circ} \mathrm{C}(\mathrm{SCF})$. The incorporation of Fe into the B site of the LSC catalyst allowed the use of a lower calcination temperature to form a phase pure perovskite. The surface area of the catalyst remained consistent at $15 \mathrm{~m}^{2} \mathrm{~g}^{-1}$ without Fe (LSC), to $13 \mathrm{~m}^{2} \mathrm{~g}^{-1}$ with Fe. As the surface area of the LSCF SAS catalyst is similar to the citric acid prepared sample, a similar catalytic activity was expected. However, this was not the case as the citric acid LSCF catalyst achieved a $\mathrm{T}_{50}$ of $448^{\circ} \mathrm{C}$, while the catalysts prepared by SAS achieved had a $\mathrm{T}_{50}$ of only $577^{\circ} \mathrm{C}$. The LSCF oxalic catalyst was found to be less active when compared to LSCF citric, as the $T_{50}$ increased from 448 to $475^{\circ} \mathrm{C}$ (Fig. 5, Table 3). The surface area of the LSCF catalysts remained consistent across preparation methods, from $12-14 \mathrm{~m}^{2} \mathrm{~g}^{-1}$ (Table 3), indicating that for this set of catalysts the surface area does not determine the catalytic activity.
As suggested previously, the concentration of certain oxygen species present in the perovskite may play a large part in the activity. XPS can be used to determine the oxygen species present, with four main species: lattice oxygen from lanthanide elements, lattice oxygen from transition metals, surface hydroxyl species or molecular water $[65,88]$. The LSCF catalysts prepared by the three different preparation methods all have these four oxygen species, with large peaks associated to lattice oxygen present in all catalysts (Fig. 6). By incorporating Fe into LSCF citric, the percentage of surface lattice oxygen species decreased slightly from $42 \%$ in LSC to $34 \%$ in LSCF citric, however, this is a large increase on the $1 \%$ seen in the SCF catalyst. This is possible even though all perovskites have an $\mathrm{ABO}_{3}$ composition, all the catalysts have slightly different crystal structures. This depends on the ratio and size of the $\mathrm{A}$ and $\mathrm{B}$ site cations and the resulting $\mathrm{A}-\mathrm{O}$ and $\mathrm{B}-\mathrm{O}$ bond lengths. These catalysts have rhombohedral and cubic structures, of varying distortions. As a result, there are differing numbers of oxygen vacancies and lattice oxygen depending on the structural flexibility before collapse [89]. As the concentration of surface lattice oxygen and the surface area have remained constant in the LSC to LSCF catalysts, this indicates that another factor is contributing to the increase in activity for this catalyst. The lattice oxygen concentration decreased from $34 \%$ in the citric acid prepared catalyst to $29 \%$ in the SAS prepared catalyst, despite the comparable surface area. This resulted in a large decrease in activity, the $\mathrm{T}_{50}$ increased from 448 (citric) to $577{ }^{\circ} \mathrm{C}$ (SAS), which could be due to a combination of the decrease in lattice oxygen and a reduction in purity between the two catalysts: the catalyst prepared using citric acid has a purity of $100 \%$ but the catalyst prepared by SAS has a purity of only $93 \%$. LSCF oxalic has a lattice oxygen concentration of $34 \%$, the same as the LSCF citric catalyst, however a decrease in $\mathrm{N}_{2} \mathrm{O}$ conversion was noted, $\left(\mathrm{T}_{50}\right.$ increased from 448 to $475^{\circ} \mathrm{C}$ ) (Fig. 5). Although

Table 3 Comparison between all catalysts, preparation method, composition determined by MP-AES, surface area, phase purity and the temperature required for $50 \%$ conversion $\left(\mathrm{T}_{50}\right)$

\begin{tabular}{|c|c|c|c|c|c|c|c|c|c|}
\hline Catalyst & $\begin{array}{l}\text { Preparation } \\
\text { method }\end{array}$ & $\begin{array}{l}\text { Pre-treat- } \\
\text { ment temp } \\
\left({ }^{\circ} \mathrm{C}\right)\end{array}$ & $\begin{array}{l}\text { Calcina- } \\
\text { tion temp } \\
\left({ }^{\circ} \mathrm{C}\right)\end{array}$ & $\begin{array}{l}\text { Composition deter- } \\
\text { mined by MP-AES }\end{array}$ & $\begin{array}{l}\text { Perovskite } \\
\text { phase purity } \\
(\%)^{\mathrm{a}}\end{array}$ & $\begin{array}{l}\text { Surface } \\
\text { area }\left(\mathrm{m}^{2}\right. \\
\left.\mathrm{g}^{-1}\right)\end{array}$ & $\mathrm{T}_{50}\left({ }^{\circ} \mathrm{C}\right)$ & $\begin{array}{l}\mathrm{N}_{2} \mathrm{O} \text { decom- } \\
\text { position rate } \\
\text { at } 450{ }^{\circ} \mathrm{C}(\mathrm{mol} \\
\left.\mathrm{h}^{-1} \mathrm{~kg}^{-1}\right)\end{array}$ & $\begin{array}{l}\text { Surface } \\
\text { Lattice O } \\
(\%)^{\mathrm{b}}\end{array}$ \\
\hline LSC & Citric acid & 200 & 900 & $\mathrm{La}_{0.8} \mathrm{Sr}_{0.4} \mathrm{CoO}_{3.9}$ & 98 & 15 & 468 & 15.2 & 42 \\
\hline SCF & Citric acid & 200 & 900 & $\mathrm{Sr}_{1.5} \mathrm{CoFe}_{0.2} \mathrm{O}_{5}$ & 81 & 7 & 585 & 1.8 & 1 \\
\hline LSCF & Citric acid & 200 & 550 & $\mathrm{LaSr}_{0.5} \mathrm{CoFe}_{0.1} \mathrm{O}_{5.8}$ & 100 & 13 & 448 & 22.8 & 34 \\
\hline LSCF & SAS & 300 & 800 & $\begin{array}{l}\mathrm{La}_{0.8} \mathrm{Sr}_{0.1} \mathrm{CoFe} \\
{ }_{0.2} \mathrm{O}_{5.2}\end{array}$ & 93 & 12 & 577 & 4.6 & 29 \\
\hline LSCF & Oxalic & 300 & 750 & $\mathrm{La}_{1} \mathrm{Sr}_{0.3} \mathrm{CoFe}_{0.2} \mathrm{O}_{5.5}$ & 100 & 14 & 475 & 17.2 & 34 \\
\hline
\end{tabular}

${ }^{\text {a}}$ Perovskite phase purity calculated using XRD diffraction pattern and the ratio between the single perovskite phase and any impurities.

${ }^{b}$ Lattice oxygen calculated by the ratio of lattice oxygen species to the sum of molecular water, transition metal lattice oxygen, hydroxyl species, as derived from XPS measurements. 
Fig. 5 Effect of preparation method on LSCF catalysts for $\mathrm{N}_{2} \mathrm{O}$ decomposition over the temperature range of 200 to $600{ }^{\circ} \mathrm{C}$. Reaction conditions: $1 \% \mathrm{~N}_{2} \mathrm{O} / \mathrm{He}$, total flow $100 \mathrm{~mL} \mathrm{~min}^{-1}$. Filled squareLSCF Citric, filled triangleLSCF SAS, filled circle-LSCF Oxalic. If error bars are not present, then smaller than symbol and less than $1 \%$

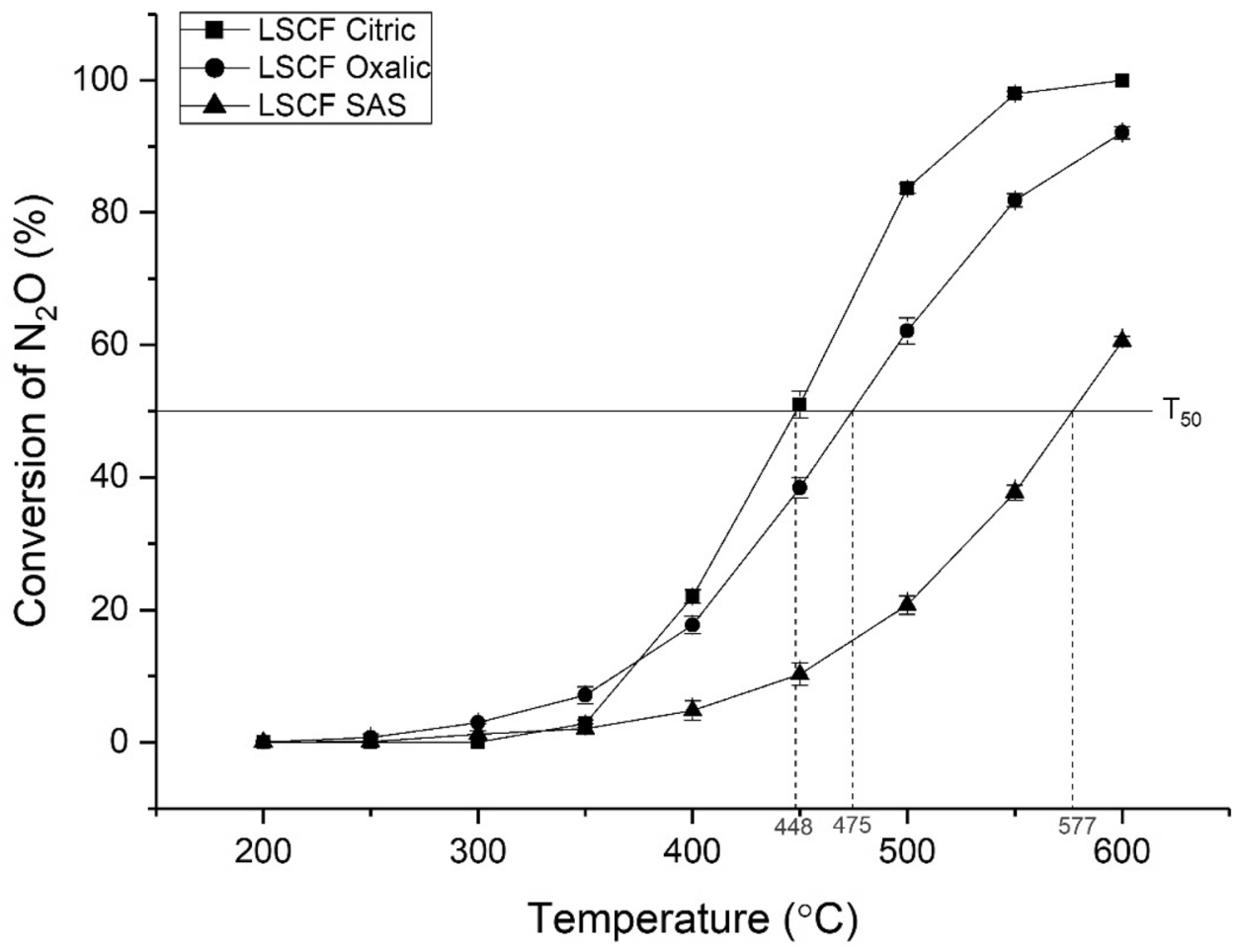

Fig. 6 XPS O $1 s$ region of all LSCF catalysts. Fittings: Red-lattice $\mathrm{O}^{2-}$, Blue-lattice $\mathrm{O}^{2-}$ transition metals, OrangeCarbonate $\mathrm{CO}_{3}{ }^{2-}$ or hydroxyl species $\mathrm{OH}^{-}$, and Purplemolecular water on surface

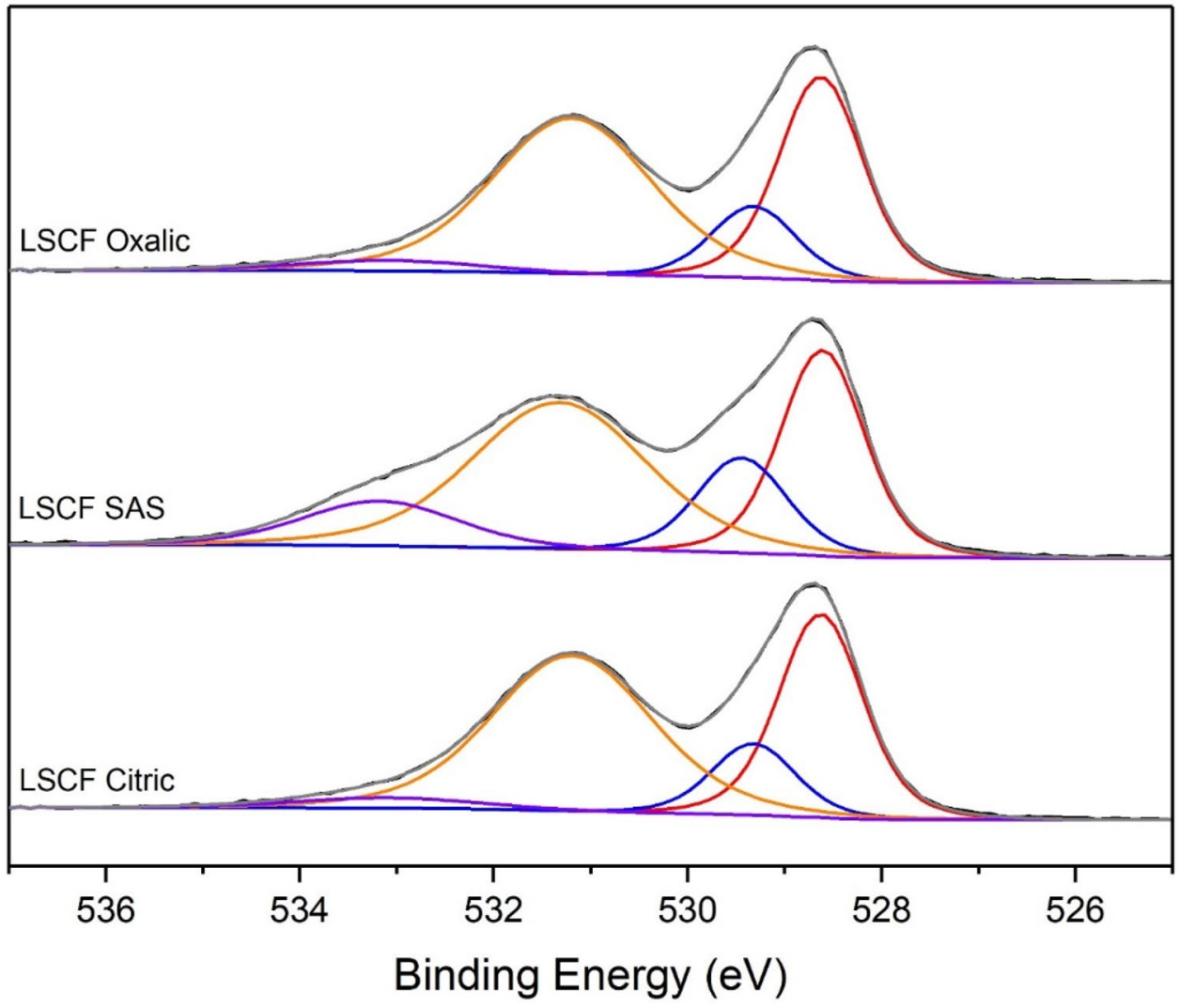


both catalysts have the same percentage of lattice oxygen, the mobility of the species present may be different. If all the oxygen present in the $\mathrm{O} 1 s 531 \mathrm{eV}$ peak is carbonate then the $\mathrm{C} 1 \mathrm{~s}$ peak at $289 \mathrm{eV}$ should be three times as large, due to the ratio of $\mathrm{C}$ and $\mathrm{O}$ in $\mathrm{CO}_{3}{ }^{2-}$, therefore $\mathrm{C} 1 s / \mathrm{O} 1 s=3$, means only contribution from carbonate, if larger then contribution from carbonate and hydroxyl. The lanthanum $3 d$ XPS spectra (Fig. S4) shows that all lanthanum containing catalysts have both lanthanum oxide and lanthanum carbonate present. As you can see from the data in Table S3, the SCF and LSCF SAS catalyst have only carbonate species present, but the LSC, LSCF Citric and LSCF Oxalic have both carbonate and hydroxyl species present at the surface. The catalysts that have only carbonate species present have poor catalytic activity, this could be due to a carbonate layer forming over the surface and blocking the active sites.

To expand the investigation into the oxygen species $\mathrm{O}_{2}$-TPD was used to compare the mobility of the lattice oxygen species in the LSCF catalysts [28, 33]. Desorption below $300{ }^{\circ} \mathrm{C}$ indicates that chemically adsorbed $\mathrm{O}_{2}$ is present. $\alpha$-Oxygen desorbs at $300-550{ }^{\circ} \mathrm{C}$, which is oxygen that is removed from the surface to form an oxygen vacancy [26, 76]. An oxygen vacancy is formed when oxygen is removed from the surface lattice structure, in the form of $\mathrm{O}_{2}$ or $\mathrm{H}_{2} \mathrm{O}$, creating a defect site $[90,91]$. Finally, above $550{ }^{\circ} \mathrm{C}$, bulk lattice oxygen $(\beta-\mathrm{O})$ desorbs $[92,93]$. When comparing the $\mathrm{O}_{2}$-TPD profiles of the three catalysts it is possible to compare the mobility of the lattice oxygen present. As there was no response in the region $<700{ }^{\circ} \mathrm{C}$, only $\beta$-oxygen (also referred to as lattice oxygen) was present $[26,76]$. A larger signal response during the $\mathrm{O}_{2}$-TPD indicates a higher mobility of lattice oxygen present. The lower the temperature at which a response is measured, the more mobile the oxygen species present are [26, 76]. As mobility increases, the activity of the catalysts should also increase if the mobility of the oxygen is as important as previously described [93, 94]. In addition to lattice oxygen being required, oxygen mobility has also been shown to be crucial in the decomposition of $\mathrm{N}_{2} \mathrm{O}$ due to the requirement to recombine $\mathrm{O}$ to form $\mathrm{O}_{2}$ in the rate determining step. If there is a large amount of lattice oxygen present that is mobile, this can then react with atomic $\mathrm{O}$ from the dissociated $\mathrm{N}_{2} \mathrm{O}$, forming $\mathrm{O}_{2}$ and regenerating the active site. Figure 7 a displays the $\mathrm{O}_{2}$-TPD profiles of LSCF prepared by the three preparation methods. As predicted by XPS, the SAS preparation produced the catalyst with the lowest response, with the onset of desorption at the highest temperature; this corresponds to lattice oxygen that is not mobile, hence producing a poorly active catalyst. The catalyst is not completely inactive, due to the small signal response seen at around $700{ }^{\circ} \mathrm{C}$ that corresponds to a small amount of mobile lattice oxygen. The oxalic and citric catalysts have similar responses at $750{ }^{\circ} \mathrm{C}$, therefore, we consider that the mobility of the lattice oxygen is similar at these temperatures and hence why at low temperatures the activity of the catalysts is similar. All catalysts show no response in the $\mathrm{O}_{2}$-TPD between 300 and $700{ }^{\circ} \mathrm{C}$, which is the region where $\alpha$-Oxygen is present $[26,76]$. $\alpha$-Oxygen is also referred to as oxygen desorbed to form oxygen vacancies; this indicates that there are a very limited number of oxygen vacancies within this series of catalysts. Oxygen vacancies are important in this reaction as it is thought that the oxygen of $\mathrm{N}_{2} \mathrm{O}$ could bind at a vacancy site and then initiate the decomposition of $\mathrm{N}_{2} \mathrm{O}$, as shown in Scheme 1.

If there are a limited number of the oxygen vacancies, then the catalyst may be limited in activity. The citric acid prepared catalyst produced a larger signal response than that of the oxalic catalyst above $750{ }^{\circ} \mathrm{C}$ and therefore has more mobile and available lattice oxygen for reaction. The properties of the catalysts are summarised in Table 3 with their activity for $\mathrm{N}_{2} \mathrm{O}$ decomposition $\left(\mathrm{T}_{50}\right)$. The $\mathrm{H}_{2}$-TPR shows the reducibility of the perovskites and therefore gives an indication about the mobility of the oxygen species due to the strength of the $\mathrm{Co}-\mathrm{O}$ bond [74]. As mentioned previously; the reduction of surface-adsorbed $\mathrm{O}$ species or nonstoichiometric excess oxygen reduction of oxygen species, including oxygen adsorbed on the oxygen deficiency, take place between 200 and $300{ }^{\circ} \mathrm{C}[75,76]$ Followed by the step wise reduction of $\mathrm{Co}^{3+}$ to $\mathrm{Co}^{2+}$ between 200 and $360{ }^{\circ} \mathrm{C}$ and $\mathrm{Co}^{2+}$ to $\mathrm{Co}^{0}$ between 450 and $540{ }^{\circ} \mathrm{C}[77,78]$. As $\mathrm{Fe}$ is the only other reducible metal in these catalysts, $\mathrm{Fe}^{3+}$ to $\mathrm{Fe}^{3+/ 2+}$ reduction takes place at around $300{ }^{\circ} \mathrm{C}$, followed by the reduction of $\mathrm{Fe}^{3+/ 2+}$ to $\mathrm{Fe}^{0}$ at around $700{ }^{\circ} \mathrm{C}$ [81]. The $\mathrm{H}_{2}$-TPR of LSCF prepared by the three preparation methods are given in Fig. 7b. LSCF SAS and oxalic show very similar $\mathrm{H}_{2}$-TPR profiles, comprised of $\mathrm{Co}^{3+}$ to $\mathrm{Co}^{2+}$ and $\mathrm{Fe}^{3+}$ to $\mathrm{Fe}^{3+/ 2+}$ reductions which occur between 250 and $450{ }^{\circ} \mathrm{C}$, followed by the simultaneous reduction of $\mathrm{Co}^{2+}$ to $\mathrm{Co}^{0}$ and $\mathrm{Fe}^{3+/ 2+}$ to $\mathrm{Fe}^{0}$ between 550 and $800^{\circ} \mathrm{C}$. The $\mathrm{H}_{2}$-TPR profile of LSCF citric is slightly different, the reduction of $\mathrm{Co}^{3+}$

$$
\begin{gathered}
\mathrm{N}_{2} \mathrm{O}_{(\text {gas })}+\mathrm{O}_{v a c} \rightarrow \mathrm{N}_{2} \mathrm{O}_{(\text {ads })} \\
\mathrm{N}_{2} \mathrm{O}_{(\text {ads })} \rightarrow \mathrm{N}_{2(\text { gas })}+O_{(\text {ads })} \\
O_{(a d s)}+O_{(a d s)} \rightarrow O_{2(g a s)}+2 O_{v a c}
\end{gathered}
$$

Scheme $1 \mathrm{~N}_{2} \mathrm{O}$ decomposition mechanism on the surface of a perovskite. Showing the use of oxygen vacancies $\left(O_{v a c}\right)$ and the importance of the mobility of lattice oxygen $\left(O_{a d s}\right)$ 

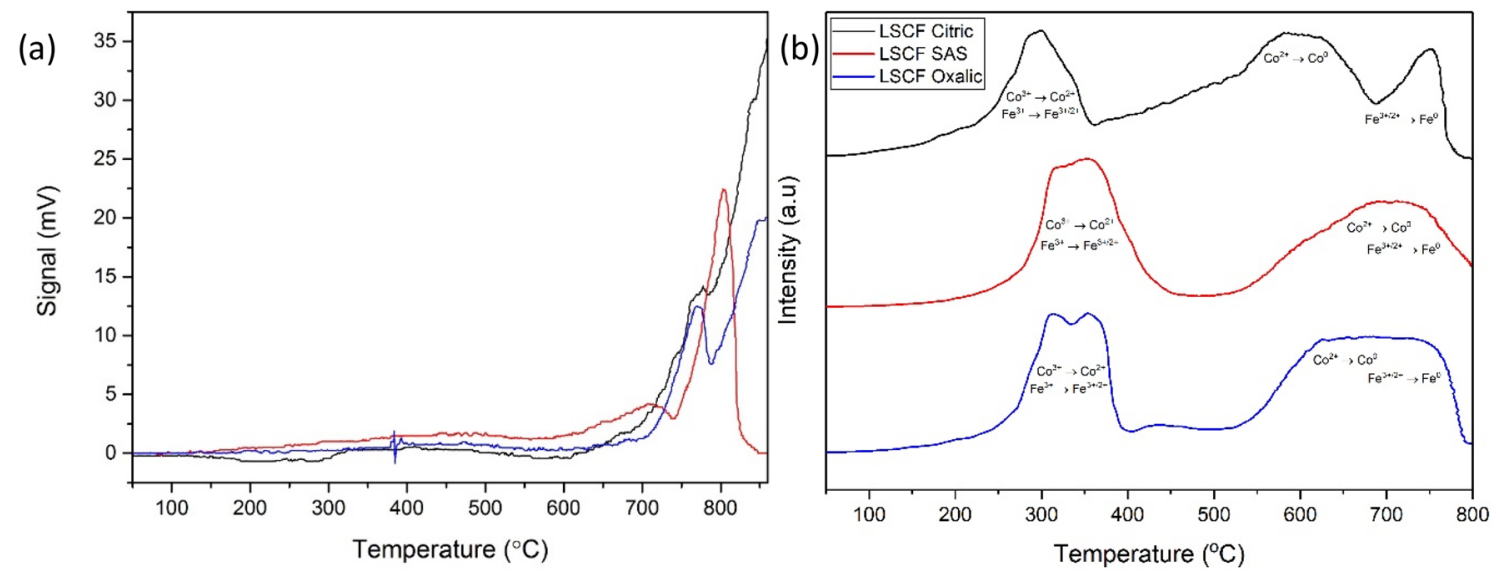

Fig. 7 a Oxygen temperature programmed desorption $\left(\mathrm{O}_{2}\right.$-TPD) of LSCF catalysts, Black-Citric prep, Red-SAS prep, Blue-Oxalic prep. b $\mathrm{H}_{2}$-TPR of all LSCF catalysts, performed at $5{ }^{\circ} \mathrm{C} \mathrm{min}^{-1}$ up to $800{ }^{\circ} \mathrm{C}$, under a flow of $10 \% \mathrm{H}_{2} / \mathrm{Ar}$.

to $\mathrm{Co}^{2+}$ and $\mathrm{Fe}^{3+}$ to $\mathrm{Fe}^{3+/ 2+}$ occurs at a slightly lower temperature between 200 and $350{ }^{\circ} \mathrm{C}$, followed by the reduction of $\mathrm{Co}^{2+}$ to $\mathrm{Co}^{0}$ between 500 and $700{ }^{\circ} \mathrm{C}$, with the final step assigned to the reduction of $\mathrm{Fe}^{3+/ 2+}$ to $\mathrm{Fe}^{0}$ between 690 and $780{ }^{\circ} \mathrm{C}$. The decreases in the reduction temperature of the Co species in LSCF Citric indicates that the Co-O bond strength is weaker and the mobility of the oxygen species is increased, which is vital for $\mathrm{N}_{2} \mathrm{O}$ decomposition, as the recombination of surface oxygen is commonly the rate determining step $[34,35]$. The combination of $\mathrm{H}_{2}-\mathrm{TPR}$ and $\mathrm{O}_{2}$-TPD indicate why the LSCF citric catalyst is the most active for $\mathrm{N}_{2} \mathrm{O}$ decomposition, due to the presence of a weaker $\mathrm{Co}-\mathrm{O}$ bond, and an increased oxygen mobility, aiding the recombination of oxygen species enabling the regeneration of active sites on the surface of the catalyst.

The Co $2 p$ XPS spectra is shown in Fig. S8, all catalysts have a peak present at $779.2 \mathrm{eV}$ due to the presence of $\mathrm{Co}_{3} \mathrm{O}_{4}$, this is a mixed oxidation state of $\mathrm{Co}(\mathrm{II})$ and $\mathrm{Co}(\mathrm{III})$ [63]. The presence of $\mathrm{Co}$ (II) species leads to the formation of a satellite at $c a .789 \mathrm{eV}$ [63]. The broader the line shape the greater the $\mathrm{Co}{ }^{2+/ 3+}$ ratio, therefore the catalyst with the lowest $\mathrm{Co}^{2+/ 3+}$ is LSC, followed by LSCF Oxalic and LSCF SAS [95, 96]. This indicates that these catalysts have very little redox capabilities. This is confirmed by $\mathrm{H}_{2}$-TPR which shows a high reduction temperature required for the reduction of $\mathrm{Co}$, indicating a strong $\mathrm{Co}-\mathrm{O}$ bond, this subsequently limits the activity of the catalysts. Both the LSC and LSCF Citric have a much broader line shape than the other catalysts and these are the two most active catalysts. The improved catalytic activity can be attributed to the improved redox capabilities as shown by XPS and, in the case of LSCF citric, $\mathrm{H}_{2}$-TPR.

The most active LSCF catalyst was tested at $450{ }^{\circ} \mathrm{C}$ for $24 \mathrm{~h}$ to give an indication of the stability of the catalysts under reaction conditions (Fig. S9). The LCSF citric catalyst has a slight induction period of $c a .1 .5 \mathrm{~h}$, but the catalyst did not lose any activity over the time-period tested.

LSCF citric catalyst has a $\mathrm{T}_{50}$ of $448{ }^{\circ} \mathrm{C}$ and a decomposition rate of $22.8 \mathrm{~mol} \mathrm{~h}^{-1} \mathrm{~kg}^{-1}$, this compares to Kumar et al. with a $\mathrm{T}_{50}$ of $442{ }^{\circ} \mathrm{C}$ and a decomposition rate of $1.2 \mathrm{~mol} \mathrm{~h}^{-1} \mathrm{~kg}^{-1}$ using a $\operatorname{Pr}_{0.2} \mathrm{Ba}_{0.8} \mathrm{MnO}_{3}$ catalyst [29], and Hutchings and co-workers who prepared a $\operatorname{Pr}_{0.75} \mathrm{Ba}_{0.25} \mathrm{CoO}_{3}$ catalyst that has a $\mathrm{T}_{50}$ of $410{ }^{\circ} \mathrm{C}$ and a decomposition rate of $32 \mathrm{~mol} \mathrm{~h}^{-1} \mathrm{~kg}^{-1}$ [33], therefore the LSCF is amongst the most active in literature.

\section{Conclusions}

We have shown that by altering the ratios of the A and $\mathrm{B}$ site cations it is possible to produce a pure phase perovskite at low temperatures, and by varying the preparation method it is possible to produce perovskites with different ratios of oxygen species. This work confirms the importance of lattice oxygen species that have high oxygen mobility for the decomposition of $\mathrm{N}_{2} \mathrm{O}$. Mobile lattice oxygen has been shown to be crucial, as the rate-limiting step in the decomposition of $\mathrm{N}_{2} \mathrm{O}$ is the formation of molecular oxygen. This is limited by adsorbed $\mathrm{O}$ species being close enough for recombination. However, if there are mobile lattice oxygen species present then these can aid recombination and regenerate the active site for $\mathrm{N}_{2} \mathrm{O}$ decomposition. In the case of LSCF the activity correlates with the weaker $\mathrm{Co}-\mathrm{O}$ bond and more mobile lattice oxygen present. The most mobile lattice oxygen, and therefore highest activity, was obtained with the citric acid preparation. LSCF citric catalyst has a $\mathrm{T}_{50}$ of $448^{\circ} \mathrm{C}$ and a decomposition rate of $22.8 \mathrm{~mol} \mathrm{~h}^{-1} \mathrm{~kg}^{-1}$ compared to other perovskites used in literature for $\mathrm{N}_{2} \mathrm{O}$ decomposition this is amongst the most active. 
Supplementary Information The online version contains supplementary material available at https://doi.org/10.1007/s10562-021-03619-3.

Acknowledgements We thank the ERC for funding 'After the GoldRush' code, ERC-AtG-291319

\section{Compliance with ethical standards}

Conflict of interests The authors declare they have no conflict of interests.

Open Access This article is licensed under a Creative Commons Attribution 4.0 International License, which permits use, sharing, adaptation, distribution and reproduction in any medium or format, as long as you give appropriate credit to the original author(s) and the source, provide a link to the Creative Commons licence, and indicate if changes were made. The images or other third party material in this article are included in the article's Creative Commons licence, unless indicated otherwise in a credit line to the material. If material is not included in the article's Creative Commons licence and your intended use is not permitted by statutory regulation or exceeds the permitted use, you will need to obtain permission directly from the copyright holder. To view a copy of this licence, visit http://creativecommons.org/licenses/by/4.0/.

\section{References}

1. Elkins J, Dlugokencky E, Hall B, et al (2020). https://www.n2ole vels.org/. Accessed 27 May 2020

2. Pérez-Ramírez J, Kapteijn F, Schöffel K, Moulijn JA (2003) Appl Catal B Environ 44:117-151

3. Weimann J (2003) Best Pract Res Clin Anaesthesiol 17:47-61

4. Forster P, Ramaswamy V (2007) In: Climate Change 2007: The Physical Science Basis. Contribution of Working Group I to the Fourth Assessment Report of the Intergovernmental Panel on Climate Change, pp 131-234

5. Intergovernmental Panel on Climate Change (2008) Climate change 2007: synthesis report. Intergovernmental Panel on Climate Change

6. Intergovernmental Panel on Climate Change (2013) Climate Change 2013: the physical science basis. Contribution of Working Group I to the Fifth Assessment Report of the Intergovernmental Panel on Climate Change

7. Maroufi SS, Gharavi MJ, Behnam M, Samadikuchaksaraei A (2011) Iran J Public Health 40:75-79

8. Kapteijn F, Rodriguez-Mirasol J, Moulijn JA (1996) Appl Catal B Environ 9:25-64

9. Zabilskiy M, Erjavec B, Djinović P, Pintar A (2014) Chem Eng J 254:153-162

10. Zhou H, Hu P, Huang $\mathrm{Z}$ et al (2013) Ind Eng Chem Res 52:4504-4509

11. Abu-Zied BM, Soliman SA, Abdellah SE (2015) J Ind Eng Chem 21:814-821

12. Stelmachowski P, Maniak G, Kaczmarczyk J et al (2014) Appl Catal B Environ 146:105-111

13. Parres-Esclapez S, Illan-Gomez MJ, de Lecea CSM, Bueno-Lopez A (2010) Appl Catal B Environ 96:370-378

14. Kapteijn F, Mul G, Marbán G, et al (1996). In: 11th International Congress on Catalysis: 40th Anniversary, vol 101, pp 641-650

15. Labhasetwar N, Saravanan G, Kumar Megarajan S et al (2015) Sci Technol Adv Mater 16:036002

16. Konsolakis MI (2015) ACS Catal 5:6397-6421

17. Hwang J, Rao RR, Giordano L et al (2017) Science 358:751-756
18. Isupova LA, Alikina GM, Tsybulya SV et al (2001) Int J Inorg Mater 3:559-562

19. Huang C, Wang X, Shi Q et al (2015) Inorg Chem 54:4002-4010

20. Afzal S, Quan X, Zhang J (2017) Appl Catal B Environ 206:692-703

21. Meng L, Sun C, Wang R et al (2018) J Am Chem Soc 140:17255-17262

22. Zhang M, Dai S, Chandrabose S et al (2018) J Am Chem Soc 140:14938-14944

23. Ke W, Spanopoulos I, Tu Q et al (2019) J Am Chem Soc 141:8627-8637

24. Tanaka H, Misono M (2001) Curr Opin Solid State Mater Sci 5:381-387

25. Marchetti L, Forni L (1998) Appl Catal B Environ 15:179-187

26. Zhu J, Li H, Zhong L et al (2014) ACS Catal 4:2917-2940

27. Russo N, Mescia D, Fino D et al (2007) Ind Eng Chem Res 46:4226-4231

28. Ivanov DV, Pinaeva LG, Isupova LA et al (2013) Appl Catal A Gen 457:42-51

29. Kumar S, Vinu A, Subrt J et al (2012) Catal Today 198:125-132

30. Ivanov DV, Sadovskaya EM, Pinaeva LG, Isupova LA (2009) J Catal 267:5-13

31. Ivanov DV, Pinaeva LG, Isupova LA et al (2011) Catal Lett. 141:322-331

32. Ishihara T, Ando M, Sada K et al (2003) J Catal 220:104-114

33. Richards N, Carter JH, Parker LA et al (2020) ACS Catal 10:5430-5442

34. Guesmi H, Berthomieu D, Kiwi-Minsker L (2008) J Phys Chem C 112:20319-20328

35. Sang C, Kim BH, Lund CRF (2005) J Phys Chem B 109:2295-2301

36. Hansen N, Heyden A, Bell AT, Keil FJ (2007) J Phys Chem C 111:2092-2101

37. Bulushev DA, Kiwi-minsker L, Renken A (2004) Ind Eng Chem Res 211:2004

38. Sun K, Xia H, Hensen E et al (2006) J Catal 238:186-195

39. Pirngruber GD (2003) J Catal 219:456-463

40. Wood B, Reimer JA, Bell AT (2002) J Catal 209:151-158

41. Pirngruber GD, Roy PK, Prins R (2007) J Catal 246:147-157

42. Richards N, Nowicka E, Carter JH et al (2018) Top Catal 61:1983-1992

43. Peña MA, Fierro JLG (2001) Chem Rev 101:1981-2017

44. Ishikawa S, Jones DR, Iqbal S et al (2017) Green Chem 19:225-236

45. Evans CD, Kondrat SA, Smith PJ et al (2016) Faraday Discuss 188:427-450

46. Hutchings GJ, Bartley JK, Lopez-Sanchez JA et al (2001) J Catal 197:232-235

47. Marin RP, Kondrat SA, Pinnell RK et al (2013) Appl Catal B Environ 140-141:671-679

48. Miedziak PJ, Tang Z, Davies TE et al (2009) Appl Catal B Environ 19:8619-8627

49. Trikalitis PN, Pomonis PJ (1995) Appl Catal A Gen 131:309-322

50. Buassi-Monroy OS, Luhrs CC, Chávez-Chávez A, Michel CR (2004) Mater Lett 58:716-718

51. Majid A, Tunney J, Argue S et al (2005) J Alloys Compd 398:48-54

52. Robert R, Logvinovich D, Aguirre MH et al (2010) Acta Mater 58:680-691

53. Deganello F, Marcì G, Deganello G (2009) J Eur Ceram Soc 29:439-450

54. Sihaib Z, Puleo F, Pantaleo G et al (2019) Catalysts 9:1-18

55. Xia Z, Sun J, Du H et al (2010) J Mater Sci 45:1553-1559

56. Thermofisher (2019) https://xpssimplified.com/elements/prase odymium.php. Accessed 19 Mar 2019 
57. Thermofisher (2019) https://xpssimplified.com/elements/barium. php. Accessed 19 Mar 2019

58. Thermofisher (2019) https://xpssimplified.com/elements/stron tium.php. Accessed 19 Mar 2019

59. Thermofisher (2019) https://xpssimplified.com/elements/lanth anum.php. Accessed 19 Mar 2019

60. Fierro JLG, Tejuca LG (1987) Appl Surf Sci 27:453-457

61. Tabata K, Hirano Y, Suzuki E (1998) Appl Catal A Gen 170:245-254

62. Thermofisher (2019) https://xpssimplified.com/elements/iron.php. Accessed 19 Mar 2019

63. Thermofisher (2019) https://xpssimplified.com/elements/cobalt. php. Accessed 19 Mar 2019

64. Morris MA, Connell MO, Norman AK, Hu CF (1999) Catal Today 47:123-132

65. Worayingyong A, Kangvansura P, Kityakarn S (2008) Colloids Surf A Physicochem Eng Asp 320:123-129

66. Zhang-Steenwinkel Y, Beckers J, Bliek A (2002) Appl Catal A Gen 235:79-92

67. Kumar S, Teraoka Y, Joshi AG et al (2011) J Mol Catal A Chem 348:42-54

68. Wang P, Yao L, Wang M, Wu W (2000) J Alloys Compd 311:53-56

69. Stoch J (1991) J Alloys Compd 17:165-167

70. Niania M, Podor R, Britton TB et al (2018) J Mater Chem A 6:14120-14135

71. Thermofisher (2020) https://xpssimplified.com/elements/carbon. php. Accessed 23 Jun 2020

72. Tanigawa S, Takashima T, Irie H (2017) J Mater Sci Chem Eng 05:129-141

73. Dupin JC, Gonbeau D, Vinatier P, Levasseur A (2000) Phys Chem Chem Phys 2:1319-1324

74. Sadykov VA, Bulgakov NN, Muzykantov VS et al (2004) Mixed ionic electronic conducting perovskites for advanced energy systems. Springer, Dordrecht, pp 53-74

75. Gu Q, Wang L, Wang Y, Li X (2019) J Phys Chem Solids 133:52-58

76. Zhu J, Zhao Z, Xiao D et al (2005) J Mol Catal A Chem 238:35-40

77. Osazuwa OU, Cheng CK (2017) J Clean Prod 148:202-211

78. Fierro JLG, Peña MA, González Tejuca L (1988) J Mater Sci 23:1018-1023
79. Erdenee N, Enkhnaran U, Galsan S, Pagvajav A (2017) J Nanomater 2017:1-8

80. Kuznetsova T, Sadykov V, Batuev L et al (2005) React Kinet Catal Lett 86:249-256

81. Pour AN, Taghipoor S, Shekarriz M et al (2009) J Nanosci Nanotechnol 9:4425-4429

82. Voorhoeve RJH, Johnson DW, Remeika JP, Gallagher PK (1977) Science 195:827-833

83. Centi G, Perathoner S (2008) Microporous Mesoporous Mater 107:3-15

84. Alini S, Basile F, Blasioli S et al (2007) Appl Catal B Environ 70:323-329

85. Dacquin JP, Dujardin C, Granger P (2008) Catal Today 137:390-396

86. Yuan J, Li SS, Yu L et al (2013) Energy Environ Sci 6:3308-3313

87. Wang L-C, Liu Q, Chen M et al (2007) J Phys Chem C 111:16549-16557

88. Merino NA, Barbero BP, Eloy P, Cadús LE (2006) Appl Surf Sci 253:1489-1493

89. Ji Q, Bi L, Zhang J et al (2020) Energy Environ Sci 13:1408-1428

90. Puigdollers AR, Schlexer P, Tosoni S, Pacchioni G (2017) ACS Catal 7:6493-6513

91. Liu L, Zhou F, Wang L et al (2010) J Catal 274:1-10

92. Pan KL, Yu SJ, Yan SY, Chang MB (2014) J Air Waste Manag Assoc 64:1260-1269

93. Dacquin JP, Lancelot C, Dujardin C et al (2009) Appl Catal B Environ 91:596-604

94. Li C, Shen Y, Zhu S, Shen S (2014) RSC Adv 4:29107-29119

95. Dudric R, Vladescu A, Rednic V et al (2014) J Mol Struct 1073:66-70

96. Giraudon JM, Elhachimi A, Leclercq G (2008) Appl Catal B Environ 84:251-261

Publisher's Note Springer Nature remains neutral with regard to jurisdictional claims in published maps and institutional affiliations.

\section{Authors and Affiliations}

\section{Nia Richards ${ }^{1}$. Luke A. Parker ${ }^{1,2}$. James H. Carter ${ }^{1}$. Samuel Pattisson ${ }^{1}$ - David J. Morgan ${ }^{1}$. Nicholas F. Dummer ${ }^{1}$. Stanislaw E. Golunski ${ }^{1}$. Graham J. Hutchings ${ }^{1}$}

1 Cardiff Catalysis Institute, School of Chemistry, Cardiff University, Cardiff CF10 3AT, UK
2 Inorganic Chemistry and Catalysis Debye Institute for Nanomaterials Science, Utrecht University, Universiteitsweg 99, 3584CG Utrecht, The Netherlands 